\title{
Impact of deadwood decomposition on soil organic carbon sequestration in Estonian and Polish forests
}

\author{
Ewa Błońska ${ }^{1} \cdot$ Jarosław Lasota ${ }^{1} \cdot$ Arvo Tullus $^{2} \cdot$ Reimo Lutter $^{3,4} \cdot$ Ivika Ostonen $^{2}$
}

Received: 9 August 2019 / Accepted: 26 September 2019 / Published online: 29 October 2019

(C) The Author(s) 2019

\begin{abstract}
- Key message The deadwood of different tree species with different decomposition rates affects soil organic carbon sequestration in Estonian and Polish forests. In warmer conditions (Poland), the deadwood decomposition process had a higher rate than in cooler Estonian forests. Soil organic matter fractions analysis can be used to assess the stability and turnover of organic carbon between deadwood and soil in different experimental localities.

- Context Deadwood is an important element of properly functioning forest ecosystem and plays a very important role in the maintenance of biodiversity, soil fertility, and carbon sequestration.

- Aims The main aim was to estimate how decomposition of deadwood of different tree species with different decomposition rates affects soil organic carbon sequestration in Estonian and Polish forests.

- Methods The investigation was carried out in six forests in Poland $\left(51^{\circ} \mathrm{N}\right)$ and Estonia $\left(58^{\circ} \mathrm{N}\right)$. The study localities differ in their mean annual air temperature (of $2{ }^{\circ} \mathrm{C}$ ) and the length of the growing season (of 1 month). The deadwood logs of Norway spruce (Picea abies (L.) Karst.), common aspen (Populus tremula L.), and silver birch (Betula pendula Roth) were included in the research. Logs in three stages of decomposition (III-V) were selected for the analysis.

- Results There were differences in the stock of soil organic carbon in two experimental localities. There was a higher soil carbon content under logs and in their direct vicinity in Polish forests compared to those in the cooler climate of Estonia. Considerable differences in the amount of soil organic matter were found. The light fraction constituted the greatest quantitative component of organic matter of soils associated with deadwood.
\end{abstract}

Handling Editor: Ana Rincón

Contribution of the co-authors Ewa Błońska: planning of work, participation in the implementation of field work and collecting data, statistical analysis, writing of the manuscript

Jarosław Lasota: implementation of field work and collecting data, statistical analysis

Arvo Tallus: implementation of field work and collecting data

Reimo Lutter: implementation of field work and collecting data

Ivika Ostonen: interpretation of results and writing of the manuscript

Ewa Błońska

eblonska@ar.krakow.pl

1 Department of Forest Soil Science, Faculty of Forestry, University of Agriculture, Al. 29 Listopada 46, 31-425 Krakow, Poland

2 Institute of Ecology and Earth Sciences, University of Tartu, Vanemuise 46, 51003 Tartu, Estonia
3 Institute of Forestry and Rural Engineering, Estonian University of Life Sciences, Kreutzwaldi 5, 51006 Tartu, Estonia

4 Department of Forest Ecology and Management, Swedish University of Agricultural Sciences, Skogsmarksgränd 17, SE-90183 Umeå, Sweden 
- Conclusion A higher carbon content in surface soil horizons as an effect of deadwood decomposition was determined for the Polish (temperate) forests. More decomposed deadwood affected soil organic matter stabilization more strongly than less decayed deadwood. This relationship was clearer in Polish forests. Higher temperatures and longer growing periods primarily influenced the increase of soil organic matter free light fraction concentrations directly under and in close proximity to logs of the studied species. The slower release of deadwood decomposition products was noted in Estonian (hemiboreal) forests. The soil organic matter mineral fraction increased under aspen and spruce logs at advanced decomposition in Poland.

Keywords Carbon accumulation $\cdot$ Decomposition stage $\cdot$ Soil organic matter fractions

\section{Introduction}

Deadwood is a ubiquitous element of both protected and managed forest ecosystems (Harmon et al. 1986; Wambsganss et al. 2017). Standing dead trees, logs, snags, and stumps constitute deadwood resources (Harmon and Sexton 1996). Deadwood is an important carbon (C) reservoir in the forest ecosystem. During the decomposition of deadwood, $\mathrm{C}$ is partly emitted to the atmosphere and partly stored as $\mathrm{C}$ resources in the soil. The main processes involved in the decomposition of deadwood are respiration, transformation, fragmentation, and leaching (Magnússon et al. 2016). Lasota et al. (2017) noted that concentration of cations leached from deadwood increases with the advancement of the decomposition rate. The amount of ions released from deadwood depends on the tree species. Increases in dissolved organic carbon (DOC) derived from decaying wood have been observed (Kahl et al. 2012; Zalamea et al. 2007). Błońska et al. (2017) demonstrated that soil $\mathrm{C}$ accumulation and enzyme activity in the soil were influenced by deadwood form, tree species, and decay class. Carbon is stored in the soil mostly as soil organic matter (SOM), and deadwood affects the quality and quantity of SOM (Zalamea et al. 2007). Soil organic matter is heterogeneous, and consists of different fractions that are characterized by different degrees of stability (Von Lützov et al. 2006). The fractionation of SOM allows the separation of groups differing in composition and biological function (Christensen 1992). Density fractionation procedure has identified three SOM fractions. The labile fraction, due to its low density $\left(<1.7 \mathrm{~g} \mathrm{~cm}^{-3}\right)$, is also called free light fraction (Tefs and Gleixner 2012). The mineral soil light fraction, however, may become stabilized by occlusion inside aggregates (resulting in the socalled occluded light fraction) (Von Lützov et al. 2006). The stabilized fraction of SOM, also known as the heavy fraction, is the mineral-associated fraction (Grüneberg et al. 2013; Saidy et al. 2012).

It is believed that, among abiotic factors, climatic conditions have the greatest impact on the soil organic matter content. Among the climatic factors, temperature and moisture are the characteristics that most influence the decomposition of soil organic matter (Bani et al. 2018; Błońska and Lasota 2017). Boreal and temperate forests cover $25 \%$ of the terrestrial land surface of the Earth. Temperate climates are those occurring between the frigid and tropical zones, having an intermediate long-term average temperature. Temperate regions generally also exhibit strong seasonality in temperature and rainfall. Climatically, the boreal region is the northernmost section of the temperate zone before the arctic begins and is coincident with the limits of continuous forest cover in the northern hemisphere (Thomas and MacLellan 2004). Hemiboreal forests form a transitional zone between boreal and temperate forest biomes and are characterized by mixed forest stands (Shorohova et al. 2009; Krasnova et al. 2019). According to Allison et al. (2009, 2013), temperature could influence decomposition of organic material by changing the activity of the decomposer community and also by changing plant species composition and litter chemistry. In a warm, humid environment, the decomposition rate is higher because such conditions favor the growth of microorganisms (Yin 1999). Dry and wet site conditions cause slower deadwood decomposition rates (Shorohova and Kapitsa 2014). Błońska and Lasota (2017) observed the highest accumulation of carbon in swampy soils where the anaerobic conditions affected the organic matter decomposition, leading to slower decompositional processes. Temperate and boreal forest soils have been proposed to sequester more carbon dioxide to reduce the pressures of climate change (Wan et al. 2011; Wiesmeier et al. 2016). It has been concluded that warming temperature under the climate change predictions will accelerate $\mathrm{C}$ turnover in forest ecosystems because of both carbon inputs via primary production and carbon losses via enhanced decomposition will increase (Stergiadi et al. 2016). Wiesmeier et al. (2016) revealed substantial soil organic carbon decreases by $11-$ $16 \%$ under an expected mean temperature increase of $3.3{ }^{\circ} \mathrm{C}$.

The main aim was to estimate how decomposition of deadwood of different tree species (Norway spruce, common aspen and silver birch) with different decomposition rates affects soil organic carbon sequestration in temperate and hemiboreal forests. For the analysis, forests with similar vegetation cover in Poland and Estonia were sampled. We tested the following hypotheses: (1) the deadwood decomposition 
process of the same tree species differs between hemiboreal and temperate forests; (2) decomposition stage of $\log s$ has inherent effect on the amount of soil organic matter; (3) heavily decomposed deadwood of all investigated species impacts soil organic matter stabilization more strongly than less decayed deadwood; (4) the light fraction of soil organic matter is more sensitive to deadwood effects than the heavy fraction.

\section{Materials and methods}

\subsection{Study sites}

The investigation was carried out in Poland and Estonia (Fig. 1). In Poland, research plots were located in Czarna Rózga Reserve $\left(50^{\circ} 59^{\prime} \mathrm{N}, 20^{\circ} 01^{\prime} \mathrm{E}\right)$. The reserve area was
185.6 ha. The stands within the boundaries of the reserve were of natural origin. The study area was characterized by the following climatic conditions: the average annual rainfall was $649 \mathrm{~mm}$; the average annual temperature was to $7.4^{\circ} \mathrm{C}$, and the growing season lasted 200-210 days (Błońska et al. 2018). In Estonia, the research plots were located in the Järvselja Training and Experimental Forest District $\left(58^{\circ} 16^{\prime}\right.$ $\left.\mathrm{N}, 27^{\circ} 18^{\prime} \mathrm{E}\right)$. That region was characterized by the following climatic conditions: the average annual rainfall was $647 \mathrm{~mm}$; the average annual temperature was $5.4^{\circ} \mathrm{C}$; and the growing season lasted 179 days (The Estonian Environment Agency: http://www.ilmateenistus.ee/). The forest stands had similar ages (the mean tree age was 95 years). The sample plots were located in an area with a predominance of fluvioglacial sand and loam with Gleysols and Cambisols (WRB 2014). The basic properties of soils investigated (at the depth $0-10 \mathrm{~cm}$ ) in Poland and Estonia are presented in Table 4.
Fig. 1 Localization of research plots and sampling scheme

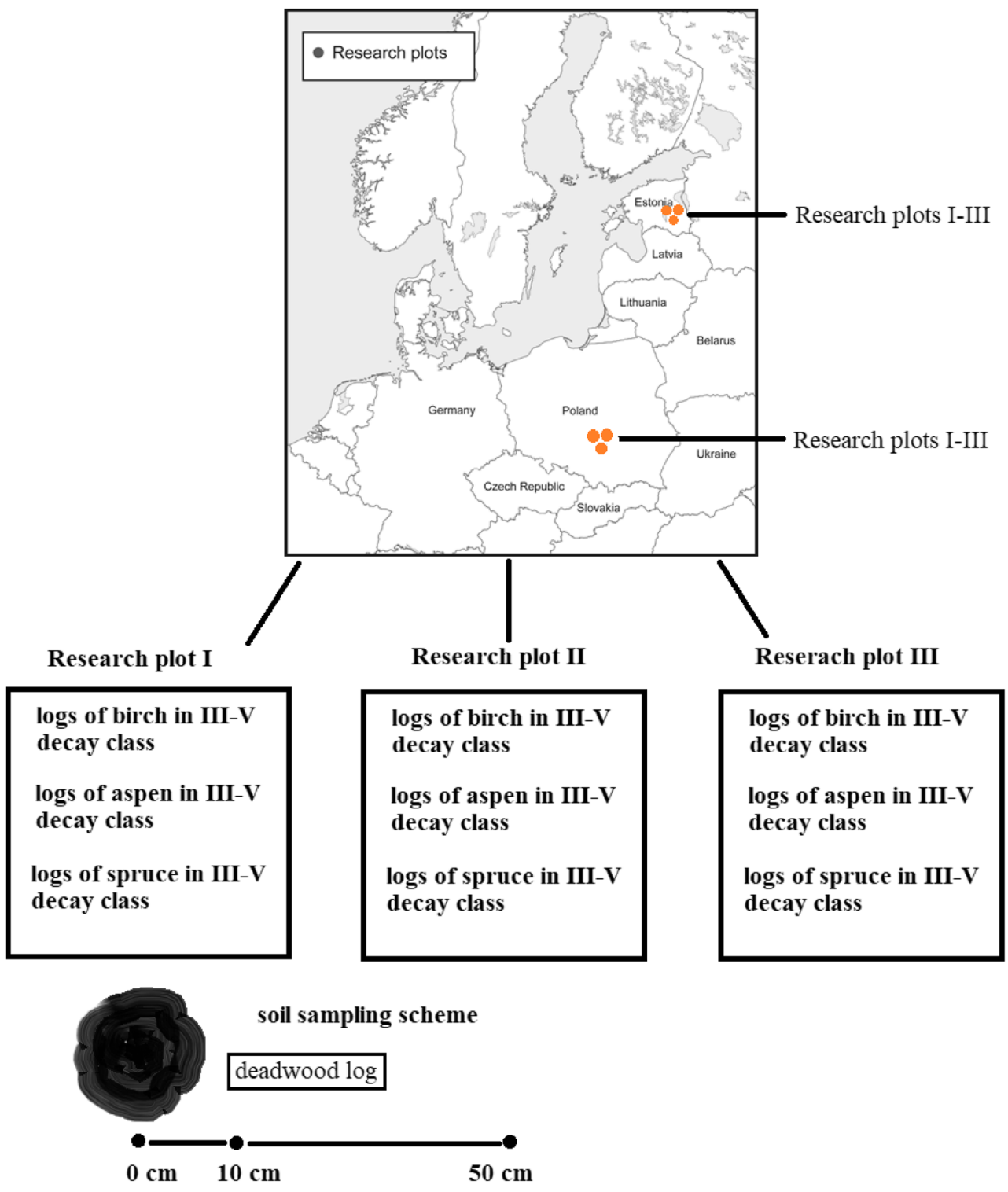




\subsection{Field design}

Research plots were selected in six forests in Poland and Estonia (three research plots in each country) (Fig. 1). On each study plot, deadwood logs of different species in different stages of decomposition (three species $\times$ three decay classes $\times$ three distance from $\operatorname{logs}(0,10$, and $50 \mathrm{~cm}))$ were chosen. Downed deadwood logs of Norway spruce (Picea abies (L.) Karst.), common aspen (Populus tremula L.), and silver birch (Betula pendula Roth) were studied. Logs in three stages of decomposition (III, IV, and V) were selected for the analysis. The decay classes (DC) of logs were evaluated with the classification of dead trees as in Maser et al. (1979) (Table 5). On each research plot, sample points were spaced apart by an average of 30-50 m. The same sampling scheme was used in both countries. The area of each plot was approximately 10 ha. Logs with similar dimensions were selected for the study, the diameter in the center of the log was between 25 $30 \mathrm{~cm}$. Soil samples under and around the logs were collected from the A horizon $(0-10 \mathrm{~cm})$ after removing the organic horizon $(\mathrm{O})$. The soil samples were collected under the logs $(0 \mathrm{~cm})$ and at two different distances from decaying logs $(10$ and $50 \mathrm{~cm}$ ) in October 2017. Eighty-one soil samples from Poland and eighty-one soil samples from Estonia were taken for laboratory analysis.

\subsection{Laboratory analysis}

The particle-size distribution of the soils was determined using laser diffraction (Analysette 22, Fritsch, IdarOberstein, Germany); $\mathrm{pH}$ was analyzed in distilled water and $1 \mathrm{M} \mathrm{KCl}$ using the potentiometric method; the content of total nitrogen $(\mathrm{N})$ and organic carbon $(\mathrm{C})$ were measured using a LECO CNS True Mac Analyzer (Leco, St. Joseph, MI, USA).

Physical separations of soil organic matter fractions were also performed (81 soil samples from Poland and 81 soil samples from Estonia). We employed a method described by Sohi et al. (2001). A 15-g sample of soil was placed in a 200-ml centrifuge tube and $90 \mathrm{ml}$ of $\mathrm{NaI}\left(1.7 \mathrm{~g} \mathrm{~cm}^{-3}\right)$ was added. Each tube was gently shaken for $1 \mathrm{~min}$ and centrifuged for $30 \mathrm{~min}$. The free light fraction (fLF) was removed using a pipette and collected on a glass fiber filter. The soil remaining at the bottom of the centrifuge tubes was mixed with another portion of $90 \mathrm{~mL}$ of $\mathrm{NaI}$ and subjected to sonication $(60 \mathrm{~W}$ for $200 \mathrm{~s})$ to destroy aggregates. After centrifugation, the matter released from the aggregateoccluded light fraction (oLF) was collected on the glass fiber filter. The remaining fraction was assumed to consist of the mineral associated fraction (MAF) of SOM. After drying $\left(40{ }^{\circ} \mathrm{C}\right)$, these subsamples were weighted and analyzed for carbon and nitrogen content $\left(\mathrm{C}_{\mathrm{fLF}}\right.$, $\mathrm{C}_{\mathrm{oLF}}, \mathrm{C}_{\mathrm{MAF}}$ and $\mathrm{N}_{\mathrm{fLF}}, \mathrm{N}_{\mathrm{oLF}}, \mathrm{N}_{\mathrm{MAF}}$ ) using a LECO
CNS True Mac Analyzer (Leco, St. Joseph, MI, USA). The database can be accessed at the following link: DOI:10.5281/zenodo.3386522.

\subsection{Statistics}

Linear mixed model (LMM) was used for the evaluation of the effect of the experimental localities, species, decay classes, and distances from log on soil carbon contents and carbon of different SOM fractions. Experimental plot and deadwood log were included as random factors to account for the spatial dependencies in data (because multiple measurements were made in each plot and next to each log). The LMM analysis was performed with the function lmer (package lme4) in R Statistics software (R Core Team 2018). Tukey's HSD multiple comparisons of means were used in post hoc analysis to assess the effect of the different experimental localities (Poland and Estonia) and distance on the studied soil properties (carbon content, nitrogen content, $\mathrm{C} / \mathrm{N}$, soil organic matter fractions). The principal component analysis (PCA) was used to identify interrelationships that exist among variables and to identify how suites of variables are related. PCA method was used to evaluate the effect of the experimental localities on carbon content and soil organic matter fractions. The statistical significance of the results was verified at the significance level of alpha $=0.05$. PCA analysis was performed with Statistica 12 Software (2012).

\section{Results}

In both experimental localities, the highest organic carbon (C) content was observed directly under the logs, and $\mathrm{C}$ content decreased gradually in subsequent samples moving away from the log outlines (Table 1). These differences intensified with the state of decay and had different levels depending on the species of deadwood. The $\mathrm{C}$ content in soil under logs in Polish plots was approximately 3-3.5-fold higher than C contents recorded for comparable conditions in Estonia. Figure 2 shows the differences in the soil organic carbon contents under the logs of different species, at the two experimental localities. Similar relationships were determined with regard to the total nitrogen contents of the experimental sites. Soil under logs analyzed at Polish plots was characterized by a higher total nitrogen content compared to soils in Estonia (Table 1). The value of the $\mathrm{C} / \mathrm{N}$ ratio in soil samples under comparable logs and at varying distances from the logs had a wide range (means from 13.2-22.0) and was similar for comparable plots in Estonia and Poland. The increase of mean $\mathrm{C} / \mathrm{N}$ ratio with the wood decay progress was clearly visible in the soil samples collected under logs (Table 1).

Considerable differences in the fraction composition of soil organic matter were found between experimental localities. 
Table 1 Carbon and nitrogen content and $\mathrm{C} / \mathrm{N}$ ratio of soils under deadwood influence in different experimental localities

\begin{tabular}{|c|c|c|c|c|c|c|c|c|}
\hline \multirow[t]{4}{*}{ Properties } & \multirow[t]{4}{*}{ Species } & \multirow[t]{4}{*}{$\mathrm{DC}$} & \multicolumn{6}{|c|}{ Experimental localities } \\
\hline & & & \multicolumn{3}{|l|}{ Estonia } & \multicolumn{3}{|l|}{ Poland } \\
\hline & & & \multicolumn{6}{|l|}{ Distance } \\
\hline & & & $0 \mathrm{~cm}$ & $10 \mathrm{~cm}$ & $50 \mathrm{~cm}$ & $0 \mathrm{~cm}$ & $10 \mathrm{~cm}$ & $50 \mathrm{~cm}$ \\
\hline \multirow[t]{9}{*}{$\mathrm{C}$} & \multirow[t]{3}{*}{ Aspen } & III & $33.3^{\mathrm{bx}}$ & $35.4^{\mathrm{ax}}$ & $45.3^{\mathrm{ax}}$ & $58.2^{\mathrm{ax}}$ & $41.3^{\mathrm{ax}}$ & $38.9^{\mathrm{ax}}$ \\
\hline & & IV & $38.1^{\mathrm{bx}}$ & $42.3^{\mathrm{bx}}$ & $38.4^{\mathrm{ax}}$ & $84.7^{\mathrm{ax}}$ & $66.5^{\text {axy }}$ & $51.9^{\text {ay }}$ \\
\hline & & $\mathrm{V}$ & $51.7^{\mathrm{bx}}$ & $33.8^{\mathrm{bx}}$ & $36.6^{\mathrm{bx}}$ & $218.2^{\mathrm{ax}}$ & $94.3^{\text {ay }}$ & $63.3^{\mathrm{az}}$ \\
\hline & \multirow[t]{3}{*}{ Birch } & III & $52.0^{\mathrm{ax}}$ & $47.5^{\mathrm{ax}}$ & $37.7^{\mathrm{ax}}$ & $72.4^{\mathrm{ax}}$ & $47.4^{\mathrm{ay}}$ & $38.9^{\text {ay }}$ \\
\hline & & IV & $66.3^{\mathrm{bx}}$ & $55.3^{\mathrm{ax}}$ & $50.3^{\mathrm{ax}}$ & $105.3^{\mathrm{ax}}$ & $72.7^{\text {ay }}$ & $55.7^{\text {ay }}$ \\
\hline & & $\mathrm{V}$ & $102.6^{\mathrm{bx}}$ & $85.8^{\text {axy }}$ & $68.1^{\text {ay }}$ & $140.3^{\mathrm{ax}}$ & $77.7^{\text {ay }}$ & $59.0^{\text {ay }}$ \\
\hline & \multirow[t]{3}{*}{ Spruce } & III & $37.5^{\mathrm{bx}}$ & $40.9^{\mathrm{bx}}$ & $33.7^{\mathrm{ax}}$ & $95.9^{\mathrm{ax}}$ & $68.9^{\text {ay }}$ & $56.1^{\text {ay }}$ \\
\hline & & IV & $36.4^{\mathrm{bx}}$ & $33.9^{\mathrm{bx}}$ & $35.7^{\mathrm{ax}}$ & $105.3^{\mathrm{ax}}$ & $60.3^{\text {ay }}$ & $32.9^{\mathrm{az}}$ \\
\hline & & $\mathrm{V}$ & $56.2^{\mathrm{bx}}$ & $42.0^{\mathrm{bxy}}$ & $35.5^{\text {by }}$ & $202.5^{\mathrm{ax}}$ & $127.2^{\text {ay }}$ & $85.3^{\mathrm{az}}$ \\
\hline \multirow[t]{9}{*}{$\mathrm{N}$} & \multirow[t]{3}{*}{ Aspen } & III & $2.6^{\mathrm{bx}}$ & $2.8^{\mathrm{ax}}$ & $3.3^{\mathrm{ax}}$ & $3.8^{\mathrm{ax}}$ & $2.7^{\text {ay }}$ & $2.8^{\text {ay }}$ \\
\hline & & IV & $2.4^{\mathrm{bx}}$ & $2.8^{\mathrm{ax}}$ & $2.6^{\mathrm{ax}}$ & $4.5^{\mathrm{ax}}$ & $3.5^{\mathrm{ay}}$ & $2.9^{\text {ay }}$ \\
\hline & & $\mathrm{V}$ & $2.8^{\mathrm{bx}}$ & $2.3^{\text {by }}$ & $2.3^{\mathrm{ay}}$ & $11.4^{\mathrm{ax}}$ & $5.1^{\mathrm{ay}}$ & $3.4^{\mathrm{az}}$ \\
\hline & \multirow[t]{3}{*}{ Birch } & III & $2.8^{\mathrm{bx}}$ & $2.6^{\mathrm{ax}}$ & $2.1^{\mathrm{ax}}$ & $4.3^{\mathrm{ax}}$ & $3.3^{\mathrm{ay}}$ & $3.0^{\text {ay }}$ \\
\hline & & IV & $3.2^{\mathrm{bx}}$ & $3.0^{\mathrm{bx}}$ & $2.8^{\mathrm{ax}}$ & $5.7^{\mathrm{ax}}$ & $4.6^{\mathrm{ay}}$ & $3.6^{\mathrm{az}}$ \\
\hline & & $\mathrm{V}$ & $4.8^{\mathrm{bx}}$ & $4.4^{\mathrm{ax}}$ & $3.6^{\mathrm{ay}}$ & $7.9^{\mathrm{ax}}$ & $5.1^{\mathrm{ay}}$ & $4.0^{\mathrm{az}}$ \\
\hline & \multirow[t]{3}{*}{ Spruce } & III & $2.3^{\mathrm{bx}}$ & $2.6^{\mathrm{ax}}$ & $2.2^{\mathrm{ax}}$ & $5.0^{\mathrm{ax}}$ & $3.6^{\mathrm{ay}}$ & $3.0^{\text {ay }}$ \\
\hline & & IV & $1.7^{\mathrm{bx}}$ & $1.9^{\mathrm{bx}}$ & $2.0^{\mathrm{ax}}$ & $6.1^{\mathrm{ax}}$ & $3.5^{\mathrm{ay}}$ & $2.2^{\mathrm{az}}$ \\
\hline & & $\mathrm{V}$ & $3.2^{\mathrm{bx}}$ & $2.9^{\mathrm{bx}}$ & $2.4^{\mathrm{bx}}$ & $9.6^{\mathrm{ax}}$ & $6.2^{\text {ay }}$ & $4.5^{\mathrm{az}}$ \\
\hline \multirow[t]{9}{*}{$\mathrm{C} / \mathrm{N}$} & \multirow[t]{3}{*}{ Aspen } & III & $13.1^{\mathrm{ax}}$ & $13.0^{\mathrm{ax}}$ & $14.2^{\mathrm{ax}}$ & $15.5^{\mathrm{ax}}$ & $15.0^{\mathrm{ax}}$ & $14.1^{\mathrm{ax}}$ \\
\hline & & IV & $15.6^{\mathrm{ax}}$ & $15.0^{\mathrm{bx}}$ & $14.4^{\mathrm{bx}}$ & $18.9^{\mathrm{ax}}$ & $19.2^{\mathrm{ax}}$ & $18.4^{\mathrm{ax}}$ \\
\hline & & $\mathrm{V}$ & $18.4^{\mathrm{ax}}$ & $14.5^{\text {by }}$ & $15.6^{\text {ay }}$ & $19.2^{\mathrm{ax}}$ & $18.3^{\mathrm{ax}}$ & $19.1^{\mathrm{ax}}$ \\
\hline & \multirow[t]{3}{*}{ Birch } & III & $18.7^{\mathrm{ax}}$ & $18.1^{\mathrm{ax}}$ & $18.4^{\mathrm{ax}}$ & $16.9^{\mathrm{ax}}$ & $14.5^{\text {bxy }}$ & $13.1^{\text {by }}$ \\
\hline & & IV & $20.7^{\mathrm{ax}}$ & $18.2^{\mathrm{ax}}$ & $18.0^{\mathrm{ax}}$ & $18.6^{\mathrm{ax}}$ & $15.8^{\text {ay }}$ & $15.7^{\text {ay }}$ \\
\hline & & V & $22.0^{\mathrm{ax}}$ & $19.5^{\text {ay }}$ & $18.7^{\text {ay }}$ & $17.9^{\mathrm{bx}}$ & $15.4^{\text {bxy }}$ & $14.8^{\text {by }}$ \\
\hline & \multirow[t]{3}{*}{ Spruce } & III & $16.2^{\mathrm{ax}}$ & $16.0^{\mathrm{ax}}$ & $15.0^{\mathrm{bx}}$ & $19.2^{\mathrm{ax}}$ & $19.5^{\mathrm{ax}}$ & $18.9^{\mathrm{ax}}$ \\
\hline & & IV & $21.4^{\mathrm{ax}}$ & $18.1^{\text {ay }}$ & $17.7^{\text {ay }}$ & $17.7^{\mathrm{bx}}$ & $18.3^{\mathrm{ax}}$ & $17.3^{\mathrm{ax}}$ \\
\hline & & $\mathrm{V}$ & $17.7^{\mathrm{ax}}$ & $14.7^{\text {by }}$ & $14.7^{\text {by }}$ & $21.0^{\mathrm{ax}}$ & $20.8^{\mathrm{ax}}$ & $19.3^{\mathrm{ax}}$ \\
\hline
\end{tabular}

DC, decay classes (III-V); 0, 10, and $50 \mathrm{~cm}$, distance from logs; $\mathrm{C}$, carbon content $\left(\mathrm{g} \mathrm{kg}^{-1}\right)$; N, nitrogen content $\left(\mathrm{g} \mathrm{kg}^{-1}\right)$; different lowercase alphabets in the upper index mean significant differences of parameters between soils from Estonia and Poland $(\mathrm{a}, \mathrm{b})$ and between distance variants $(\mathrm{x}, \mathrm{y}, \mathrm{z})$
The light fraction $\mathrm{C}$ constituted the greatest quantitative component of organic matter in soils under or near deadwood. In the Polish plots, the soil under aspen logs at III DC contained $19.2 \mathrm{~g} \mathrm{~kg}^{-1} \mathrm{C}_{\mathrm{fLF}}$ and $57.1 \mathrm{~g} \mathrm{~kg}^{-1} \mathrm{C}_{\mathrm{fLF}}$ under spruce logs (Table 2). In the cooler Estonian climate, in soil under aspen and spruce at III DC, a lower amount of free light fraction carbon was accumulated, 4.2 and $8.0 \mathrm{~g} \mathrm{~kg}^{-1} \mathrm{C}_{\mathrm{fLF}}$, respectively. In the case of birch logs, significant differences of SOM fractions between the experimental localities in Poland and Estonia were not found. The $\mathrm{C}_{\mathrm{fLF}}$ content in soil under logs at IV DC of aspen and spruce was significantly different, being higher in Poland compared to the Estonian plots. In the case of the wood at the highest decay class (V DC), differences between $\mathrm{C}_{\mathrm{fLF}}$ contents were greater for aspen and spruce wood, while in the soil under birch logs a tendency for $C_{f L F}$ increase was found ( 85.6 relative to $61.0 \mathrm{~g} \mathrm{~kg}^{-1}$ ), which was statistically significant (Table 2). The contents of occluded light fraction carbon $\left(\mathrm{C}_{\mathrm{oLF}}\right)$ in Polish and Estonian soils were influenced by the deadwood of the studied species. The mean $\mathrm{C}_{\mathrm{oLF}}$ content was $8.4-15.2 \mathrm{~g} \mathrm{~kg}^{-1}$ at III DC, 7.4 $12.9 \mathrm{~g} \mathrm{~kg}^{-1}$ at IV DC, and 13.7-18.2 $\mathrm{g} \mathrm{kg}^{-1}$ at $\mathrm{V} \mathrm{DC}$ in Estonia, and 8.6-24.0 $\mathrm{g} \mathrm{kg}^{-1}, 15.0-22.9 \mathrm{~g} \mathrm{~kg}^{-1}$, and 7.5$29.1 \mathrm{~g} \mathrm{~kg}^{-1}$ in Poland, respectively. In the case of the mineral associated fraction $\left(\mathrm{C}_{\mathrm{MAF}}\right)$ in soil collected directly under decaying logs, a significant difference was determined for this trait at III DC only in the case of spruce $\operatorname{logs}\left(30.2 \mathrm{~g} \mathrm{~kg}^{-1}\right.$ in Polish plots, $21.2 \mathrm{~g} \mathrm{~kg}^{-1}$ in Estonian plots). In soil collected under logs at IV DC, significant differences were determined 
Fig. 2 Difference in of carbon content (delta $\mathrm{C}(\mathrm{g} \mathrm{kg}-1))$ in soil directly below the deadwood between experimental localities in Poland and Estonia; III-V, decay class. The statistically significant ( $\mathrm{t}$ test) difference in $\mathrm{C}$ content in soil between Poland and Estonia is marked by an asterisk

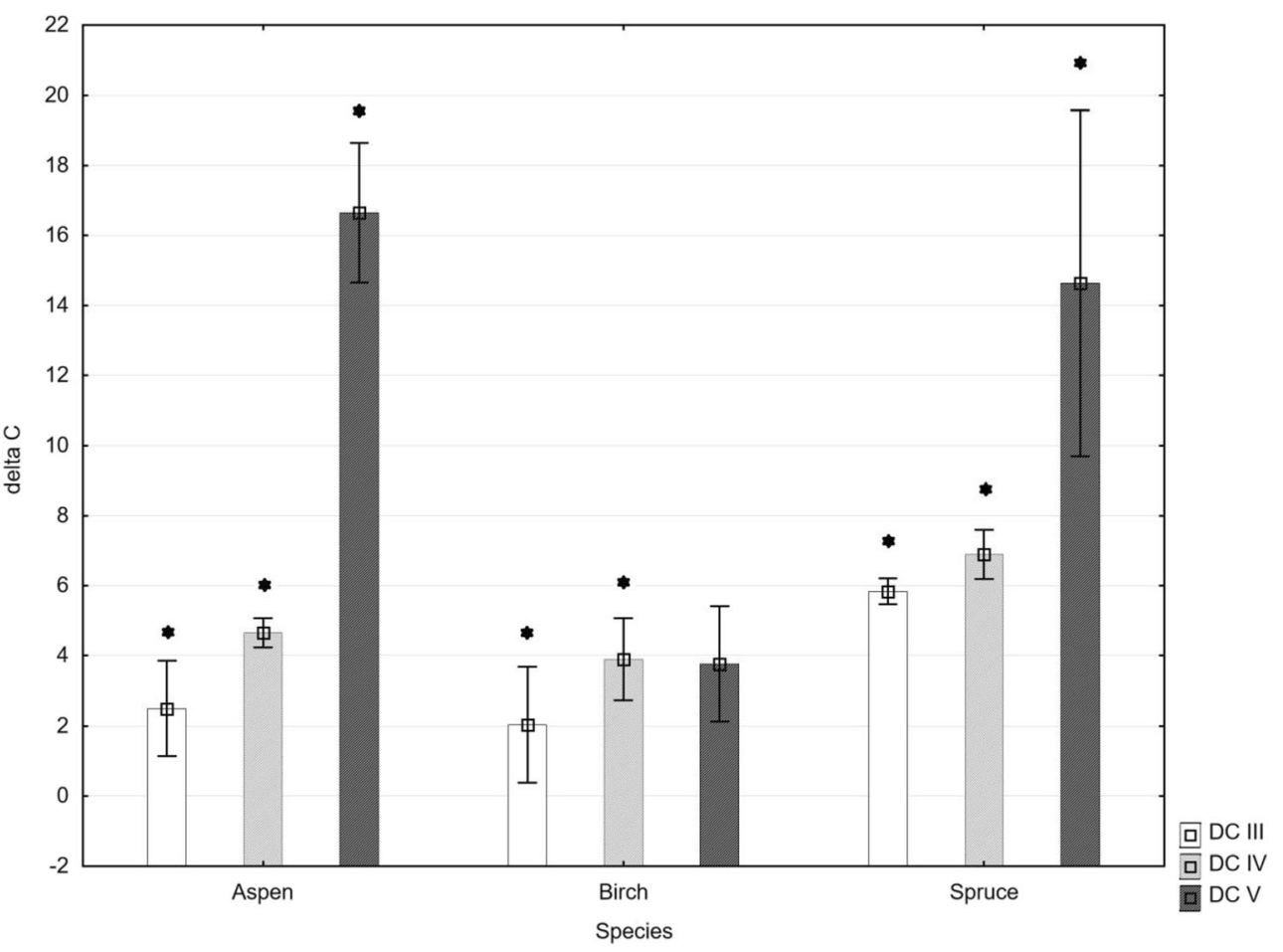

in the cases of birch $\left(21.2 \mathrm{~g} \mathrm{~kg}^{-1} \mathrm{C}_{\mathrm{MAF}}\right.$ in Poland; $11.7 \mathrm{~g} \mathrm{~kg}^{-1}$ in Estonia). Furthermore, significant differences in $\mathrm{C}_{\mathrm{MAF}}$ contents were found for soil collected under spruce and aspen logs at V DC, in the experimental localities (Table 2).

The free light fraction nitrogen content $\left(\mathrm{N}_{\mathrm{fLF}}\right)$ in soils under or near deadwood of the species studied followed the similar pattern to the carbon. In the case of spruce logs in the Polish climate, the soil located directly under logs contained significantly higher amount of $\mathrm{N}_{\mathrm{fLF}}$ at all decomposition classes of the tested logs when compared to the amount of $\mathrm{N}_{\mathrm{fLF}}$ measured in soils from Estonian plots. A higher $\mathrm{N}_{\mathrm{fLF}}$ concentration under birch and aspen logs was found for IV and V DC logs (Table 2). The nitrogen of the occluded light fraction $\left(\mathrm{N}_{\mathrm{oLF}}\right)$ had similar values in both geographical locations in comparable soils under aspen and spruce logs. Differences in the $\mathrm{N}_{\mathrm{oLF}}$ contents were observed in soils under birch logs. Nitrogen of the mineral associated fraction $\left(\mathrm{N}_{\mathrm{MAF}}\right)$ had similar values in soils of the plots studied in III and IV DC (Table 2). Differences in the $\mathrm{N}_{\mathrm{MAF}}$ contents were observed in soils under aspen and spruce logs in V DC. The fLF constitued the greatest share of the total carbon for all samples followed by the heavy fraction, regardless of experimental localities, species of deadwood and decomposition rate (Fig. 3). With the advancement of the decomposition rate, the share of the light fraction of SOM increased irrespective of the deadwood species and experimental locality. This relationship was most pronounced in the soil directly below the deadwood log (Fig. 3). The free light fraction (fLF) was characterized by a higher $\mathrm{C} / \mathrm{N}$ ratio compared to the occluded light $(\mathrm{oLF})$ and mineral associated fractions (MAF) (Table 2). Comparison of the experimental localities analyzed indicated a tendency for higher values of the $\mathrm{C} / \mathrm{N}$ ratio in all fractions in soils formed in the cooler climate of Estonia (Table 2).

The effect of the studied experimental locations on the fractional composition of the humus was also confirmed by the PCA analysis (Fig. 4). Factor 1 explained $30 \%$ of the variance of the examined properties, whereas Factor 2 accounted for $13 \%$ of the variance. The biplot of the cases on the plane of Axis 1 and 2 (Fig. 4) shows the trend to separation of groups of experimental plots from Estonia and Poland. The soils studied at Polish and Estonian plots differed in the $\mathrm{C}$ and $\mathrm{N}$ contents of individual fractions of soil organic matter. Factor 1 was related to the nitrogen content, carbon content, the carbon of light fraction of soil organic matter, and pH. Factors 2 was associated with carbon and nitrogen of occluded fraction of soil organic matter. The biplot confirmed the higher values of $\mathrm{C}_{\mathrm{fLF}}$ and $\mathrm{N}_{\mathrm{fLF}}$ on experimental locations in Poland. LMM analysis confirmed the simultaneous and strong impact of the experimental localities on carbon storage in soil under or near deadwood (Table 3). According to the LMM analysis, the experimental locality had a significant influence on the carbon of the free light fraction of SOM $(p<0.001)$ and the carbon of the heavy fraction of SOM $(p=0.0012)$. Experimental localities in connection with species and distance had a significant influence on all SOM fractions. Additionally, species of wood, decay classes, and distances from deadwood had influences on the carbon of light and heavy fractions of SOM (Table 3). 
Table 2 Carbon, nitrogen, and $\mathrm{C} / \mathrm{N}$ ratio of soil organic matter fractions of soils under deadwood influence in different experimental localities

\begin{tabular}{|c|c|c|c|c|c|c|c|c|}
\hline \multirow[t]{4}{*}{ DC } & \multirow{4}{*}{$\begin{array}{l}\mathrm{C} \text { and } \mathrm{N} \text { of } \\
\mathrm{SOM} \text { fractions }\end{array}$} & \multirow[t]{4}{*}{ Species } & \multicolumn{6}{|c|}{ Experimental localities } \\
\hline & & & \multicolumn{3}{|l|}{ Estonia } & \multicolumn{3}{|l|}{ Poland } \\
\hline & & & \multicolumn{6}{|l|}{ Distance } \\
\hline & & & $0 \mathrm{~cm}$ & $10 \mathrm{~cm}$ & $50 \mathrm{~cm}$ & $0 \mathrm{~cm}$ & $10 \mathrm{~cm}$ & $50 \mathrm{~cm}$ \\
\hline \multirow[t]{27}{*}{ III } & \multirow[t]{3}{*}{$\mathrm{C}_{\mathrm{fLF}}$} & Aspen & $4.2 \pm 2.4^{\mathrm{a}}$ & $4.5 \pm 1.6^{\mathrm{a}}$ & $10.3 \pm 3.3^{\mathrm{a}}$ & $19.2 \pm 7.1^{\mathrm{a}}$ & $14.7 \pm 7.6^{\mathrm{a}}$ & $12.3 \pm 4.3^{\mathrm{a}}$ \\
\hline & & Birch & $27.7 \pm 8.4^{\mathrm{a}}$ & $14.9 \pm 3.2^{\mathrm{a}}$ & $8.7 \pm 0.4^{\mathrm{a}}$ & $32.0 \pm 3.4^{\mathrm{a}}$ & $19.3 \pm 3.0^{\mathrm{a}}$ & $12.1 \pm 2.9^{\mathrm{a}}$ \\
\hline & & Spruce & $8.0 \pm 0.6^{\mathrm{b}}$ & $8.0 \pm 0.8^{\mathrm{b}}$ & $6.7 \pm 1.6^{\mathrm{b}}$ & $57.1 \pm 0.5^{\mathrm{a}}$ & $41.9 \pm 8.4^{\mathrm{a}}$ & $32.2 \pm 3.6^{\mathrm{a}}$ \\
\hline & \multirow{3}{*}{$\mathrm{C}_{\mathrm{oLF}}$} & Aspen & $15.2 \pm 9.9^{\mathrm{b}}$ & $14.8 \pm 9.0^{\mathrm{a}}$ & $20.2 \pm 12.1^{\mathrm{a}}$ & $24.0 \pm 3.8^{\mathrm{a}}$ & $19.9 \pm 2.2^{\mathrm{a}}$ & $17.7 \pm 1.9^{\mathrm{a}}$ \\
\hline & & Birch & $9.3 \pm 3.2^{\mathrm{b}}$ & $10.6 \pm 3.4^{\mathrm{a}}$ & $7.9 \pm 1.2^{\mathrm{b}}$ & $23.3 \pm 2.9^{\mathrm{a}}$ & $17.8 \pm 2.9^{\mathrm{a}}$ & $17.3 \pm 2.0^{\mathrm{a}}$ \\
\hline & & Spruce & $8.4 \pm 2.5^{\mathrm{a}}$ & $11.5 \pm 4.3^{\mathrm{a}}$ & $7.8 \pm 3.0^{\mathrm{a}}$ & $8.6 \pm 2.0^{\mathrm{a}}$ & $7.5 \pm 1.1^{\mathrm{a}}$ & $3.5 \pm 1.0^{\mathrm{a}}$ \\
\hline & \multirow[t]{3}{*}{$\mathrm{C}_{\mathrm{MAF}}$} & Aspen & $14.0 \pm 1.6^{\mathrm{a}}$ & $16.1 \pm 2.3^{\mathrm{a}}$ & $14.8 \pm 4.4^{\mathrm{a}}$ & $15.0 \pm 2.8^{\mathrm{a}}$ & $6.7 \pm 4.3^{\mathrm{b}}$ & $9.0 \pm 0.7^{\mathrm{a}}$ \\
\hline & & Birch & $15.0 \pm 4.0^{\mathrm{a}}$ & $21.9 \pm 9.8^{\mathrm{a}}$ & $21.0 \pm 11.0^{\mathrm{a}}$ & $17.1 \pm 1.9^{\mathrm{a}}$ & $10.4 \pm 2.2^{\mathrm{b}}$ & $9.4 \pm 0.7^{\mathrm{b}}$ \\
\hline & & Spruce & $21.2 \pm 4.2^{\mathrm{b}}$ & $21.4 \pm 3.0^{\mathrm{a}}$ & $19.2 \pm 2.3^{\mathrm{a}}$ & $30.2 \pm 2.7^{\mathrm{a}}$ & $19.5 \pm 2.9^{\mathrm{a}}$ & $20.3 \pm 6.8^{\mathrm{a}}$ \\
\hline & \multirow{3}{*}{$\mathrm{N}_{\mathrm{fLF}}$} & Aspen & $0.2 \pm 0.1^{\mathrm{a}}$ & $0.2 \pm 0.1^{\mathrm{a}}$ & $0.4 \pm 0.1^{\mathrm{a}}$ & $1.0 \pm 0.5^{\mathrm{a}}$ & $0.8 \pm 0.4^{\mathrm{a}}$ & $0.6 \pm 0.2^{\mathrm{a}}$ \\
\hline & & Birch & $1.1 \pm 0.3^{\mathrm{a}}$ & $0.5 \pm 0.1^{\mathrm{a}}$ & $0.3 \pm 0.0^{\mathrm{a}}$ & $1.4 \pm 0.3^{\mathrm{a}}$ & $1.0 \pm 0.3^{\mathrm{a}}$ & $0.8 \pm 0.2^{\mathrm{a}}$ \\
\hline & & Spruce & $0.2 \pm 0.1^{\mathrm{b}}$ & $0.3 \pm 0.0^{\mathrm{b}}$ & $0.2 \pm 0.1^{\mathrm{b}}$ & $2.9 \pm 0.3^{\mathrm{a}}$ & $2.1 \pm 0.6^{\mathrm{a}}$ & $1.6 \pm 0.3^{\mathrm{a}}$ \\
\hline & \multirow[t]{3}{*}{$\mathrm{N}_{\mathrm{oLF}}$} & Aspen & $1.1 \pm 0.8^{\mathrm{a}}$ & $1.1 \pm 0.8^{\mathrm{a}}$ & $1.5 \pm 1.0^{\mathrm{a}}$ & $1.7 \pm 0.5^{\mathrm{a}}$ & $1.3 \pm 0.2^{\mathrm{a}}$ & $1.4 \pm 0.2^{\mathrm{a}}$ \\
\hline & & Birch & $0.7 \pm 0.3^{\mathrm{b}}$ & $0.6 \pm 0.2^{\mathrm{b}}$ & $0.5 \pm 0.1^{\mathrm{b}}$ & $1.8 \pm 0.3^{\mathrm{a}}$ & $1.4 \pm 0.1^{\mathrm{a}}$ & $1.5 \pm 0.1^{\mathrm{a}}$ \\
\hline & & Spruce & $0.5 \pm 0.2^{\mathrm{a}}$ & $0.7 \pm 0.3^{\mathrm{a}}$ & $0.5 \pm 0.2^{\mathrm{a}}$ & $0.5 \pm 0.1^{\mathrm{a}}$ & $0.4 \pm 0.0^{\mathrm{a}}$ & $0.2 \pm 0.0^{\mathrm{b}}$ \\
\hline & $\mathrm{N}_{\mathrm{MAF}}$ & Aspen & $1.2 \pm 0.2^{\mathrm{a}}$ & $1.5 \pm 0.1^{\mathrm{a}}$ & $1.3 \pm 0.4^{\mathrm{a}}$ & $1.1 \pm 0.3^{\mathrm{a}}$ & $0.6 \pm 0.4^{\mathrm{b}}$ & $0.8 \pm 0.1^{\mathrm{b}}$ \\
\hline & & Birch & $1.0 \pm 0.1^{\mathrm{a}}$ & $1.5 \pm 0.5^{\mathrm{a}}$ & $1.3 \pm 0.6^{\mathrm{a}}$ & $1.1 \pm 0.3^{\mathrm{a}}$ & $0.8 \pm 0.2^{\mathrm{b}}$ & $0.8 \pm 0.1^{\mathrm{a}}$ \\
\hline & & Spruce & $1.6 \pm 0.3^{\mathrm{a}}$ & $1.6 \pm 0.1^{\mathrm{a}}$ & $1.5 \pm 0.2^{\mathrm{a}}$ & $1.7 \pm 0.1^{\mathrm{a}}$ & $1.1 \pm 0.2^{\mathrm{a}}$ & $1.2 \pm 0.4^{\mathrm{a}}$ \\
\hline & $\mathrm{C} / \mathrm{N}_{\mathrm{fLF}}$ & Aspen & $24.2 \pm 1.3^{\mathrm{a}}$ & $26.9 \pm 0.6^{\mathrm{a}}$ & $22.7 \pm 2.2^{\mathrm{a}}$ & $20.8 \pm 3.8^{\mathrm{a}}$ & $17.6 \pm 0.3^{b}$ & $19.8 \pm 2.3^{\mathrm{a}}$ \\
\hline & & Birch & $24.4 \pm 0.8^{\mathrm{a}}$ & $27.3 \pm 2.5^{\mathrm{a}}$ & $28.0 \pm 2.6^{\mathrm{a}}$ & $23.4 \pm 2.1^{\mathrm{a}}$ & $19.2 \pm 2.8^{b}$ & $15.9 \pm 1.5^{\mathrm{b}}$ \\
\hline & & Spruce & $37.2 \pm 14.3^{\mathrm{a}}$ & $29.5 \pm 3.8^{\mathrm{a}}$ & $30.6 \pm 3.0^{\mathrm{a}}$ & $19.9 \pm 1.8^{\mathrm{b}}$ & $20.1 \pm 2.3^{b}$ & $19.7 \pm 1.0^{\mathrm{b}}$ \\
\hline & $\mathrm{C} / \mathrm{N}_{\mathrm{oLF}}$ & Aspen & $13.8 \pm 1.0^{\mathrm{a}}$ & $13.6 \pm 1.1^{\mathrm{a}}$ & $13.7 \pm 1.0^{\mathrm{a}}$ & $14.6 \pm 2.3^{\mathrm{a}}$ & $15.6 \pm 3.8^{\mathrm{a}}$ & $12.9 \pm 0.8^{\mathrm{a}}$ \\
\hline & & Birch & $14.7 \pm 1.6^{\mathrm{a}}$ & $17.6 \pm 0.6^{\mathrm{a}}$ & $15.7 \pm 1.6^{\mathrm{a}}$ & $12.8 \pm 0.8^{\mathrm{a}}$ & $12.7 \pm 1.8^{\mathrm{b}}$ & $11.9 \pm 1.5^{\mathrm{a}}$ \\
\hline & & Spruce & $15.6 \pm 1.3^{\mathrm{a}}$ & $16.0 \pm 1.2^{\mathrm{a}}$ & $15.6 \pm 1.2^{\mathrm{b}}$ & $18.8 \pm 1.9^{\mathrm{a}}$ & $19.3 \pm 2.1^{\mathrm{a}}$ & $21.1 \pm 0.7^{\mathrm{a}}$ \\
\hline & $\mathrm{C} / \mathrm{N}_{\mathrm{MAF}}$ & Aspen & $11.4 \pm 0.8^{\mathrm{a}}$ & $11.0 \pm 0.6^{\mathrm{a}}$ & $11.4 \pm 0.7^{\mathrm{a}}$ & $13.8 \pm 0.7^{\mathrm{a}}$ & $11.4 \pm 0.6^{\mathrm{a}}$ & $11.9 \pm 0.7^{\mathrm{a}}$ \\
\hline & & Birch & $15.0 \pm 2.1^{\mathrm{a}}$ & $14.3 \pm 2.1^{\mathrm{a}}$ & $16.5 \pm 1.8^{\mathrm{a}}$ & $15.9 \pm 2.6^{\mathrm{a}}$ & $12.4 \pm 0.5^{\mathrm{a}}$ & $12.6 \pm 0.9^{\mathrm{b}}$ \\
\hline & & Spruce & $13.6 \pm 2.0^{\mathrm{b}}$ & $13.6 \pm 1.2^{\mathrm{b}}$ & $12.6 \pm 0.8^{\mathrm{b}}$ & $18.0 \pm 0.1^{\mathrm{a}}$ & $18.6 \pm 0.4^{\mathrm{a}}$ & $17.1 \pm 0.6^{\mathrm{a}}$ \\
\hline IV & $\mathrm{C}_{\mathrm{fLF}}$ & Aspen & $9.3 \pm 1.0^{\mathrm{b}}$ & $10.4 \pm 6.9^{\mathrm{b}}$ & $8.2 \pm 5.7^{\mathrm{a}}$ & $48.7 \pm 1.0^{\mathrm{a}}$ & $36.1 \pm 5.7^{\mathrm{a}}$ & $28.6 \pm 2.6^{\mathrm{a}}$ \\
\hline & & Birch & $42.5 \pm 7.3^{\mathrm{a}}$ & $21.6 \pm 8.0^{\mathrm{a}}$ & $15.4 \pm 5.1^{\mathrm{a}}$ & $61.1 \pm 5.3^{\mathrm{a}}$ & $36.4 \pm 4.8^{\mathrm{a}}$ & $25.6 \pm 4.9^{\mathrm{a}}$ \\
\hline & & Spruce & $13.7 \pm 2.4^{\mathrm{b}}$ & $9.2 \pm 0.5^{\mathrm{b}}$ & $9.3 \pm 3.3^{\mathrm{a}}$ & $68.0 \pm 9.2^{\mathrm{a}}$ & $35.5 \pm 6.0^{\mathrm{a}}$ & $15.3 \pm 2.5^{\mathrm{a}}$ \\
\hline & $\mathrm{C}_{\mathrm{oLF}}$ & Aspen & $12.9 \pm 4.2^{\mathrm{a}}$ & $14.2 \pm 5.6^{\mathrm{a}}$ & $17.7 \pm 9.4^{\mathrm{a}}$ & $15.0 \pm 7.9^{\mathrm{a}}$ & $16.3 \pm 5.5^{\mathrm{a}}$ & $8.4 \pm 3.7^{\mathrm{b}}$ \\
\hline & & Birch & $12.0 \pm 5.0^{\mathrm{b}}$ & $13.9 \pm 2.7^{\mathrm{a}}$ & $11.4 \pm 1.0^{\mathrm{a}}$ & $22.9 \pm 7.0^{\mathrm{a}}$ & $21.1 \pm 5.0^{\mathrm{a}}$ & $15.3 \pm 1.8^{\mathrm{a}}$ \\
\hline & & Spruce & $7.4 \pm 1.4^{\mathrm{b}}$ & $10.4 \pm 5.0^{\mathrm{a}}$ & $13.1 \pm 5.3^{\mathrm{a}}$ & $18.9 \pm 1.2^{\mathrm{a}}$ & $12.6 \pm 3.7^{\mathrm{a}}$ & $12.7 \pm 5.4^{\mathrm{a}}$ \\
\hline & $\mathrm{C}_{\mathrm{MAF}}$ & Aspen & $16.0 \pm 2.0^{\mathrm{a}}$ & $17.7 \pm 4.1^{\mathrm{a}}$ & $12.5 \pm 4.2^{\mathrm{a}}$ & $21.0 \pm 8.8^{\mathrm{a}}$ & $14.1 \pm 4.3^{\mathrm{a}}$ & $15.0 \pm 3.5^{\mathrm{a}}$ \\
\hline & & Birch & $11.7 \pm 4.4^{\mathrm{b}}$ & $19.8 \pm 5.7^{\mathrm{a}}$ & $23.4 \pm 2.9^{\mathrm{a}}$ & $21.2 \pm 3.5^{\mathrm{a}}$ & $15.2 \pm 1.2^{\mathrm{a}}$ & $14.7 \pm 1.9^{b}$ \\
\hline & & Spruce & $15.2 \pm 1.4^{\mathrm{a}}$ & $14.3 \pm 2.9^{\mathrm{a}}$ & $13.3 \pm 1.9^{\mathrm{a}}$ & $18.4 \pm 1.2^{\mathrm{a}}$ & $12.2 \pm 3.8^{\mathrm{a}}$ & $5.0 \pm 3.4^{\mathrm{b}}$ \\
\hline & $\mathrm{N}_{\mathrm{fLF}}$ & Aspen & $0.3 \pm 0.0^{\mathrm{b}}$ & $0.4 \pm 0.3^{\mathrm{b}}$ & $0.3 \pm 0.2^{\mathrm{b}}$ & $2.5 \pm 0.2^{\mathrm{a}}$ & $1.9 \pm 0.4^{\mathrm{a}}$ & $1.5 \pm 0.3^{\mathrm{a}}$ \\
\hline & TLF & Birch & $1.7 \pm 0.4^{\mathrm{b}}$ & $0.9 \pm 0.3^{\mathrm{b}}$ & $0.6 \pm 0.2^{\mathrm{a}}$ & $2.7 \pm 0.2^{\mathrm{a}}$ & $2.0 \pm 0.3^{\mathrm{a}}$ & $1.5 \pm 0.0^{\mathrm{a}}$ \\
\hline & & Spruce & $0.4 \pm 0.1^{\mathrm{b}}$ & $0.3 \pm 0.0^{\mathrm{b}}$ & $0.3 \pm 0.1^{\mathrm{a}}$ & $3.6 \pm 0.3^{\mathrm{a}}$ & $1.7 \pm 0.2^{\mathrm{a}}$ & $0.9 \pm 0.3^{\mathrm{a}}$ \\
\hline & $\mathrm{N}_{\mathrm{oLF}}$ & Aspen & $0.9 \pm 0.3^{\mathrm{a}}$ & $1.0 \pm 0.4^{\mathrm{a}}$ & $1.2 \pm 0.6^{\mathrm{a}}$ & $0.8 \pm 0.4^{\mathrm{a}}$ & $0.8 \pm 0.3^{\mathrm{a}}$ & $0.5 \pm 0.2^{\mathrm{b}}$ \\
\hline & & Birch & $0.7 \pm 0.3^{\mathrm{b}}$ & $0.9 \pm 0.1^{\mathrm{a}}$ & $0.7 \pm 0.1^{\mathrm{b}}$ & $1.6 \pm 0.5^{\mathrm{a}}$ & $1.4 \pm 0.2^{\mathrm{a}}$ & $1.1 \pm 0.1^{\mathrm{a}}$ \\
\hline & & Spruce & $0.4 \pm 0.1^{\mathrm{b}}$ & $0.6 \pm 0.3^{\mathrm{a}}$ & $0.8 \pm 0.4^{\mathrm{a}}$ & $1.2 \pm 0.3^{\mathrm{a}}$ & $0.8 \pm 0.4^{\mathrm{a}}$ & $0.8 \pm 0.6^{\mathrm{a}}$ \\
\hline & $\mathrm{N}_{\mathrm{MAF}}$ & Aspen & $1.2 \pm 0.1^{\mathrm{a}}$ & $1.4 \pm 0.2^{\mathrm{a}}$ & $1.1 \pm 0.3^{\mathrm{a}}$ & $1.2 \pm 0.6^{\mathrm{a}}$ & $0.8 \pm 0.4^{\mathrm{b}}$ & $0.9 \pm 0.4^{\mathrm{a}}$ \\
\hline & & Birch & $0.8 \pm 0.4^{\mathrm{a}}$ & $1.3 \pm 0.4^{\mathrm{a}}$ & $1.5 \pm 0.3^{\mathrm{a}}$ & $1.3 \pm 0.3^{\mathrm{a}}$ & $1.2 \pm 0.3^{\mathrm{a}}$ & $1.0 \pm 0.1^{\mathrm{a}}$ \\
\hline & & Spruce & $0.9 \pm 0.1^{\mathrm{a}}$ & $1.0 \pm 0.2^{\mathrm{a}}$ & $0.9 \pm 0.1^{\mathrm{a}}$ & $1.3 \pm 0.2^{\mathrm{a}}$ & $0.9 \pm 0.4^{\mathrm{a}}$ & $0.4 \pm 0.3^{\mathrm{a}}$ \\
\hline & $\mathrm{C} / \mathrm{N}_{\mathrm{fLF}}$ & Aspen & $27.7 \pm 3.7^{\mathrm{a}}$ & $24.1 \pm 0.5^{\mathrm{a}}$ & $24.9 \pm 2.3^{\mathrm{a}}$ & $19.5 \pm 1.5^{\mathrm{b}}$ & $18.9 \pm 0.8^{\mathrm{a}}$ & $19.3 \pm 1.6^{\mathrm{b}}$ \\
\hline & & Birch & $26.0 \pm 2.8^{\mathrm{a}}$ & $25.5 \pm 1.2^{\mathrm{a}}$ & $25.9 \pm 1.2^{\mathrm{a}}$ & $22.5 \pm 0.6^{\mathrm{a}}$ & $17.9 \pm 0.9^{b}$ & $17.6 \pm 3.1^{\mathrm{b}}$ \\
\hline & & Spruce & $34.6 \pm 1.1^{\mathrm{a}}$ & $33.9 \pm 3.0^{\mathrm{a}}$ & $29.7 \pm 1.3^{\mathrm{a}}$ & $19.3 \pm 4.0^{\mathrm{b}}$ & $20.8 \pm 5.1^{\mathrm{b}}$ & $18.7 \pm 4.6^{b}$ \\
\hline & $\mathrm{C} / \mathrm{N}_{\mathrm{oLF}}$ & Aspen & $14.6 \pm 0.6^{\mathrm{a}}$ & $14.3 \pm 0.9^{b}$ & $14.1 \pm 0.6^{\mathrm{a}}$ & $17.9 \pm 1.3^{\mathrm{a}}$ & $19.8 \pm 5.2^{\mathrm{a}}$ & $16.8 \pm 1.7^{\mathrm{a}}$ \\
\hline & & Birch & $16.9 \pm 0.8^{\mathrm{a}}$ & $15.4 \pm 0.8^{\mathrm{a}}$ & $16.1 \pm 1.3^{\mathrm{a}}$ & $14.5 \pm 2.0^{\mathrm{a}}$ & $14.7 \pm 3.5^{\mathrm{a}}$ & $14.0 \pm 0.8^{\mathrm{a}}$ \\
\hline & & Spruce & $18.3 \pm 0.9^{\mathrm{a}}$ & $17.1 \pm 2.1^{\mathrm{a}}$ & $16.7 \pm 1.3^{\mathrm{a}}$ & $16.0 \pm 3.2^{\mathrm{a}}$ & $16.8 \pm 4.9^{\mathrm{a}}$ & $17.5 \pm 5.5^{\mathrm{a}}$ \\
\hline & $\mathrm{C} / \mathrm{N}_{\mathrm{MAF}}$ & Aspen & $13.3 \pm 1.6^{\mathrm{b}}$ & $13.0 \pm 2.3^{b}$ & $11.7 \pm 0.9^{\mathrm{b}}$ & $18.5 \pm 1.6^{\mathrm{a}}$ & $19.8 \pm 3.5^{\mathrm{a}}$ & $18.1 \pm 3.1^{\mathrm{a}}$ \\
\hline & & Birch & $14.7 \pm 1.9^{\mathrm{a}}$ & $15.7 \pm 0.9^{\mathrm{a}}$ & $15.8 \pm 1.4^{\mathrm{a}}$ & $16.1 \pm 2.5^{\mathrm{a}}$ & $13.7 \pm 3.8^{\mathrm{a}}$ & $14.8 \pm 1.7^{\mathrm{a}}$ \\
\hline & & Spruce & $17.0 \pm 1.3^{\mathrm{a}}$ & $14.5 \pm 0.1^{\mathrm{a}}$ & $14.5 \pm 0.9^{\mathrm{a}}$ & $14.9 \pm 3.5^{\mathrm{a}}$ & $14.9 \pm 4.1^{\mathrm{a}}$ & $13.0 \pm 3.1^{\mathrm{a}}$ \\
\hline V & $\mathrm{C}_{\mathrm{fLF}}$ & Aspen & $14.3 \pm 5.3^{\mathrm{b}}$ & $6.0 \pm 3.5^{\mathrm{b}}$ & $11.0 \pm 6.7^{\mathrm{a}}$ & $172.8 \pm 44.6^{\mathrm{a}}$ & $63.8 \pm 24.2^{\mathrm{a}}$ & $31.4 \pm 11.5^{\mathrm{a}}$ \\
\hline & & Birch & $61.0 \pm 26.5^{\mathrm{b}}$ & $52.2 \pm 25.5^{\mathrm{a}}$ & $42.1 \pm 26.6^{\mathrm{a}}$ & $85.6 \pm 14.6^{\mathrm{a}}$ & $40.9 \pm 1.9^{\mathrm{a}}$ & $25.0 \pm 6.9^{\mathrm{a}}$ \\
\hline & & Spruce & $22.4 \pm 2.7^{\mathrm{b}}$ & $10.0 \pm 3.2^{\mathrm{b}}$ & $9.3 \pm 3.3^{\mathrm{b}}$ & $134.3 \pm 56.8^{\mathrm{a}}$ & $83.2 \pm 25.8^{\mathrm{a}}$ & $53.8 \pm 22.2^{\mathrm{a}}$ \\
\hline & $\mathrm{C}_{\mathrm{oLF}}$ & Aspen & $15.9 \pm 3.0^{\mathrm{a}}$ & $14.3 \pm 4.0^{\mathrm{a}}$ & $17.5 \pm 5.7^{\mathrm{a}}$ & $5.0 \pm 6.8^{\mathrm{b}}$ & $15.9 \pm 6.0^{\mathrm{a}}$ & $14.0 \pm 10.9^{\mathrm{a}}$ \\
\hline & & Birch & $18.2 \pm 11.8^{b}$ & $14.5 \pm 6.5^{\mathrm{a}}$ & $10.0 \pm 4.6^{\mathrm{a}}$ & $29.1 \pm 8.7^{\mathrm{a}}$ & $17.1 \pm 3.0^{\mathrm{a}}$ & $15.8 \pm 7.8^{\mathrm{a}}$ \\
\hline
\end{tabular}


Table 2 (continued)

\begin{tabular}{|c|c|c|c|c|c|c|c|c|}
\hline \multirow[t]{4}{*}{ DC } & \multirow{4}{*}{$\begin{array}{l}\mathrm{C} \text { and } \mathrm{N} \text { of } \\
\mathrm{SOM} \text { fractions }\end{array}$} & \multirow[t]{4}{*}{ Species } & \multicolumn{6}{|c|}{ Experimental localities } \\
\hline & & & \multicolumn{3}{|l|}{ Estonia } & \multicolumn{3}{|l|}{ Poland } \\
\hline & & & \multicolumn{6}{|l|}{ Distance } \\
\hline & & & $0 \mathrm{~cm}$ & $10 \mathrm{~cm}$ & $50 \mathrm{~cm}$ & $0 \mathrm{~cm}$ & $10 \mathrm{~cm}$ & $50 \mathrm{~cm}$ \\
\hline \multirow{4}{*}{\multicolumn{2}{|c|}{$\mathrm{C}_{\mathrm{MAF}}$}} & Spruce & $13.7 \pm 3.1^{\mathrm{a}}$ & $12.7 \pm 2.6^{\mathrm{a}}$ & $9.9 \pm 4.0^{\mathrm{a}}$ & $13.7 \pm 4.7^{\mathrm{a}}$ & $7.2 \pm 2.3^{\mathrm{a}}$ & $6.6 \pm 3.0^{\mathrm{a}}$ \\
\hline & & Aspen & $21.5 \pm 6.7^{b}$ & $13.5 \pm 3.9^{\mathrm{a}}$ & $8.1 \pm 2.7^{\mathrm{b}}$ & $40.5 \pm 9.8^{\mathrm{a}}$ & $14.5 \pm 3.3^{\mathrm{a}}$ & $17.9 \pm 3.1^{\mathrm{a}}$ \\
\hline & & Birch & $23.4 \pm 7.3^{\mathrm{a}}$ & $19.1 \pm 4.3^{\mathrm{a}}$ & $15.9 \pm 2.3^{\mathrm{a}}$ & $25.7 \pm 3.6^{\mathrm{a}}$ & $19.7 \pm 1.3^{\mathrm{a}}$ & $18.1 \pm 1.2^{\mathrm{a}}$ \\
\hline & & Spruce & $20.1 \pm 3.4^{\mathrm{b}}$ & $19.4 \pm 1.5^{\mathrm{b}}$ & $16.4 \pm 1.5^{\mathrm{b}}$ & $54.5 \pm 7.6^{\mathrm{a}}$ & $36.8 \pm 6.3^{\mathrm{a}}$ & $24.9 \pm 2.7^{\mathrm{a}}$ \\
\hline \multirow{3}{*}{\multicolumn{2}{|c|}{$\mathrm{N}_{\mathrm{fLF}}$}} & Aspen & $0.5 \pm 0.3^{\mathrm{b}}$ & $0.2 \pm 0.1^{\mathrm{b}}$ & $0.6 \pm 0.4^{\mathrm{b}}$ & $9.0 \pm 1.7^{\mathrm{a}}$ & $3.3 \pm 1.1^{\mathrm{a}}$ & $1.5 \pm 0.7^{\mathrm{a}}$ \\
\hline & & Birch & $2.7 \pm 1.2^{\mathrm{b}}$ & $2.3 \pm 1.0^{\mathrm{a}}$ & $1.8 \pm 1.1^{\mathrm{a}}$ & $4.5 \pm 0.1^{\mathrm{a}}$ & $2.5 \pm 0.1^{\mathrm{a}}$ & $1.5 \pm 0.5^{\mathrm{a}}$ \\
\hline & & Spruce & $0.8 \pm 0.1^{\mathrm{b}}$ & $0.4 \pm 0.1^{\mathrm{b}}$ & $0.4 \pm 0.2^{\mathrm{b}}$ & $6.2 \pm 1.8^{\mathrm{a}}$ & $3.9 \pm 1.2^{\mathrm{a}}$ & $2.6 \pm 1.0^{\mathrm{a}}$ \\
\hline \multirow{3}{*}{\multicolumn{2}{|c|}{$\mathrm{N}_{\mathrm{oLF}}$}} & Aspen & $0.9 \pm 0.2^{\mathrm{a}}$ & $1.0 \pm 0.4^{\mathrm{a}}$ & $1.0 \pm 0.4^{\mathrm{a}}$ & $0.5 \pm 0.4^{\mathrm{a}}$ & $1.0 \pm 0.4^{\mathrm{a}}$ & $0.8 \pm 0.7^{\mathrm{a}}$ \\
\hline & & Birch & $0.7 \pm 0.1^{\mathrm{b}}$ & $1.0 \pm 0.8^{\mathrm{a}}$ & $0.7 \pm 0.5^{\mathrm{a}}$ & $1.6 \pm 0.1^{\mathrm{a}}$ & $1.1 \pm 0.2^{\mathrm{a}}$ & $1.0 \pm 0.5^{\mathrm{a}}$ \\
\hline & & Spruce & $0.9 \pm 0.2^{\mathrm{a}}$ & $0.9 \pm 0.3^{\mathrm{a}}$ & $0.7 \pm 0.3^{\mathrm{a}}$ & $0.7 \pm 0.3^{\mathrm{a}}$ & $0.4 \pm 0.2^{\mathrm{a}}$ & $0.4 \pm 0.3^{\mathrm{a}}$ \\
\hline \multirow{3}{*}{\multicolumn{2}{|c|}{$\mathrm{N}_{\mathrm{MAF}}$}} & Aspen & $1.4 \pm 0.3^{\mathrm{b}}$ & $1.1 \pm 0.2^{\mathrm{a}}$ & $0.8 \pm 0.4^{\mathrm{a}}$ & $2.0 \pm 0.6^{\mathrm{a}}$ & $0.8 \pm 0.0^{\mathrm{a}}$ & $1.1 \pm 0.2^{\mathrm{a}}$ \\
\hline & & Birch & $1.4 \pm 0.2^{\mathrm{a}}$ & $1.1 \pm 0.2^{\mathrm{a}}$ & $1.0 \pm 0.1^{\mathrm{a}}$ & $1.7 \pm 0.6^{\mathrm{a}}$ & $1.5 \pm 0.4^{\mathrm{a}}$ & $1.5 \pm 0.3^{\mathrm{a}}$ \\
\hline & & Spruce & $1.5 \pm 0.1^{\mathrm{b}}$ & $1.5 \pm 0.1^{\mathrm{a}}$ & $1.4 \pm 0.0^{\mathrm{a}}$ & $2.7 \pm 0.8^{\mathrm{a}}$ & $1.9 \pm 0.7^{\mathrm{a}}$ & $1.5 \pm 0.5^{\mathrm{a}}$ \\
\hline \multirow{3}{*}{\multicolumn{2}{|c|}{$\mathrm{C} / \mathrm{N}_{\mathrm{fLF}}$}} & Aspen & $29.9 \pm 5.3^{\mathrm{a}}$ & $24.9 \pm 1.8^{\mathrm{a}}$ & $20.9 \pm 6.9^{\mathrm{a}}$ & $19.0 \pm 1.7^{b}$ & $19.0 \pm 2.0^{\mathrm{b}}$ & $21.7 \pm 5.0^{\mathrm{a}}$ \\
\hline & & Birch & $22.8 \pm 1.6^{\mathrm{a}}$ & $22.8 \pm 2.7^{\mathrm{a}}$ & $23.4 \pm 1.6^{\mathrm{a}}$ & $18.9 \pm 2.8^{\mathrm{a}}$ & $16.3 \pm 1.5^{\mathrm{b}}$ & $17.2 \pm 3.2^{\mathrm{b}}$ \\
\hline & & Spruce & $28.8 \pm 1.6^{\mathrm{a}}$ & $25.5 \pm 3.1^{\mathrm{a}}$ & $26.1 \pm 4.2^{\mathrm{a}}$ & $21.3 \pm 3.3^{b}$ & $21.4 \pm 3.3^{\mathrm{a}}$ & $20.8 \pm 3.3^{\mathrm{a}}$ \\
\hline \multirow{3}{*}{\multicolumn{2}{|c|}{$\mathrm{C} / \mathrm{N}_{\mathrm{oLF}}$}} & Aspen & $18.6 \pm 6.0^{\mathrm{a}}$ & $14.4 \pm 1.1^{\mathrm{a}}$ & $18.4 \pm 5.9^{\mathrm{a}}$ & $17.3 \pm 2.5^{\mathrm{a}}$ & $16.7 \pm 1.6^{\mathrm{a}}$ & $17.8 \pm 2.4^{\mathrm{a}}$ \\
\hline & & Birch & $28.5 \pm 22.2^{\mathrm{a}}$ & $15.7 \pm 3.9^{\mathrm{a}}$ & $15.6 \pm 3.9^{\mathrm{a}}$ & $17.7 \pm 4.0^{\mathrm{a}}$ & $15.7 \pm 0.9^{\mathrm{a}}$ & $15.5 \pm 1.1^{\mathrm{a}}$ \\
\hline & & Spruce & $15.0 \pm 0.8^{\mathrm{b}}$ & $14.0 \pm 2.0^{\mathrm{a}}$ & $15.2 \pm 1.7^{\mathrm{b}}$ & $20.7 \pm 3.0^{\mathrm{a}}$ & $16.6 \pm 1.9^{\mathrm{a}}$ & $20.0 \pm 6.6^{\mathrm{a}}$ \\
\hline \multirow{3}{*}{\multicolumn{2}{|c|}{$\mathrm{C} / \mathrm{N}_{\mathrm{MAF}}$}} & Aspen & $15.0 \pm 1.3^{\mathrm{b}}$ & $12.3 \pm 1.6^{\mathrm{b}}$ & $10.8 \pm 1.6^{\mathrm{b}}$ & $20.1 \pm 1.8^{\mathrm{a}}$ & $17.5 \pm 3.9^{\mathrm{a}}$ & $16.4 \pm 1.0^{\mathrm{a}}$ \\
\hline & & Birch & $16.3 \pm 2.1^{\mathrm{a}}$ & $17.7 \pm 2.1^{\mathrm{a}}$ & $15.3 \pm 2.3^{\mathrm{a}}$ & $16.4 \pm 7.0^{\mathrm{a}}$ & $13.7 \pm 2.8^{\mathrm{b}}$ & $12.6 \pm 1.6^{\mathrm{a}}$ \\
\hline & & Spruce & $13.6 \pm 2.3^{b}$ & $12.6 \pm 0.5^{\mathrm{b}}$ & $11.8 \pm 1.1^{\mathrm{b}}$ & $20.8 \pm 4.6^{\mathrm{a}}$ & $20.7 \pm 4.9^{\mathrm{a}}$ & $16.9 \pm 3.6^{\mathrm{a}}$ \\
\hline
\end{tabular}

(Mean \pm Std. deviation); DC, decay classes; 0, 10, and 50, distance from logs; $\mathrm{C}_{\mathrm{fLF}}$, carbon of free light fraction $\left(\mathrm{g} \mathrm{kg}^{-1}\right) ; \mathrm{C}_{\mathrm{oLF}}, \mathrm{carbon}$ of occluded light fraction $\left(\mathrm{g} \mathrm{kg}^{-1}\right) ; \mathrm{C}_{\mathrm{MAF}}$, carbon of mineral associated fraction $\left(\mathrm{g} \mathrm{kg}^{-1}\right) ; \mathrm{N}_{\mathrm{fLF}}$, nitrogen of free light fraction $\left(\mathrm{g} \mathrm{kg}^{-1}\right)$; $\mathrm{N}_{\mathrm{oLF}}$, nitrogen of occluded light fraction $\left(\mathrm{g} \mathrm{kg}^{-1}\right)$; $\mathrm{N}_{\mathrm{MAF}}$, nitrogen of mineral associated fraction $\left(\mathrm{g} \mathrm{kg}^{-1}\right) ; \mathrm{C} / \mathrm{N}_{\mathrm{fLF}}, \mathrm{C} / \mathrm{N}$ ratio of free light fraction; $\mathrm{C} / \mathrm{N}_{\mathrm{oLF}}, \mathrm{C} / \mathrm{N}$ ratio of occluded light fraction; $\mathrm{C} / \mathrm{N}_{\mathrm{MAF}}, \mathrm{C} / \mathrm{N}$ ratio of mineral associated fraction; different lowercase alphabets in the upper index mean significant differences of parameters between soils from Estonia and Poland

\section{Discussion}

Our study showed differences in the content of soil organic matter at two experimental locations. Higher $\mathrm{C}$ contents in the upper mineral soil horizon $(0-10 \mathrm{~cm})$ under logs and in their vicinities were recorded in Polish sites compared to the sites in Estonia. The experimental locations differ in thermal conditions, which were exemplified by the differences in the mean annual air temperatures ( of $2{ }^{\circ} \mathrm{C}$ ) and the length of the growing periods (longer by approx. 31 days in the Polish locality). Our study showed that, in warmer conditions (Poland), the deadwood decomposition process had a higher rate than in cooler climate conditions (Estonia). The importance of thermal conditions for the course of the processes of transformations and accumulations of soil organic matter has been confirmed in a series of studies, and it is known to have various foundations (Kirschbaum 1995; Knorr et al. 2005; Scharlemann et al. 2014; Wiesmeier et al. 2016; Von Lützow and KögelKnabner 2009). Thermal conditions influence the activity of soil microorganisms and the mesobiota participating in the processes of decomposition as well as the humification of detritus and deadwood accumulated on the soil surface. Bardelli et al. (2017), and Egli et al. (2016), Fravolini et al. (2016, 2018), and Gómez-Brandón et al. (2017a, b) demonstrated that temperature (depending on the location-specific conditions, in mountain areas) influence the composition of microorganisms found in the soil and deadwood and their enzymatic activity, which determines the directions of the transformations and decomposition rates of soil organic matter. A tendency for higher $\mathrm{C} / \mathrm{N}$ ratio values in all soil organic matter fractions was noted in Estonia. Such outcome has been confirmed in other studies; for example, Ostonen et al. (2017) demonstrated an increase in $\mathrm{C} / \mathrm{N}$ ratio of soil organic matter and fine roots in spruce and birch forests along a climatic gradient from the temperate to the boreal zone. The soil $\mathrm{C} / \mathrm{N}$ ratio was the main factor describing the variability of absorptive fine root biomass over stand basal area, which reflected the nutrient uptake efficiency by roots, and also indicated litter quality along the climatic gradient. Higher $\mathrm{C} / \mathrm{N}$ meant a higher resistance of organic remains to decomposition and a slower decomposition rate: thus, the Estonian sites had slower rates for soil organic matter transformations and 
Fig. 3 The ratio of SOM fractions ( $\mathrm{g} \mathrm{kg}-1)$ to total carbon content ( $\mathrm{g}$ $\mathrm{kg}-1$ ) in soil under influence of deadwood of different species in different decomposition rates (III-V). Separate graphs present different distance from deadwood $(0,10$, and $50 \mathrm{~cm})$
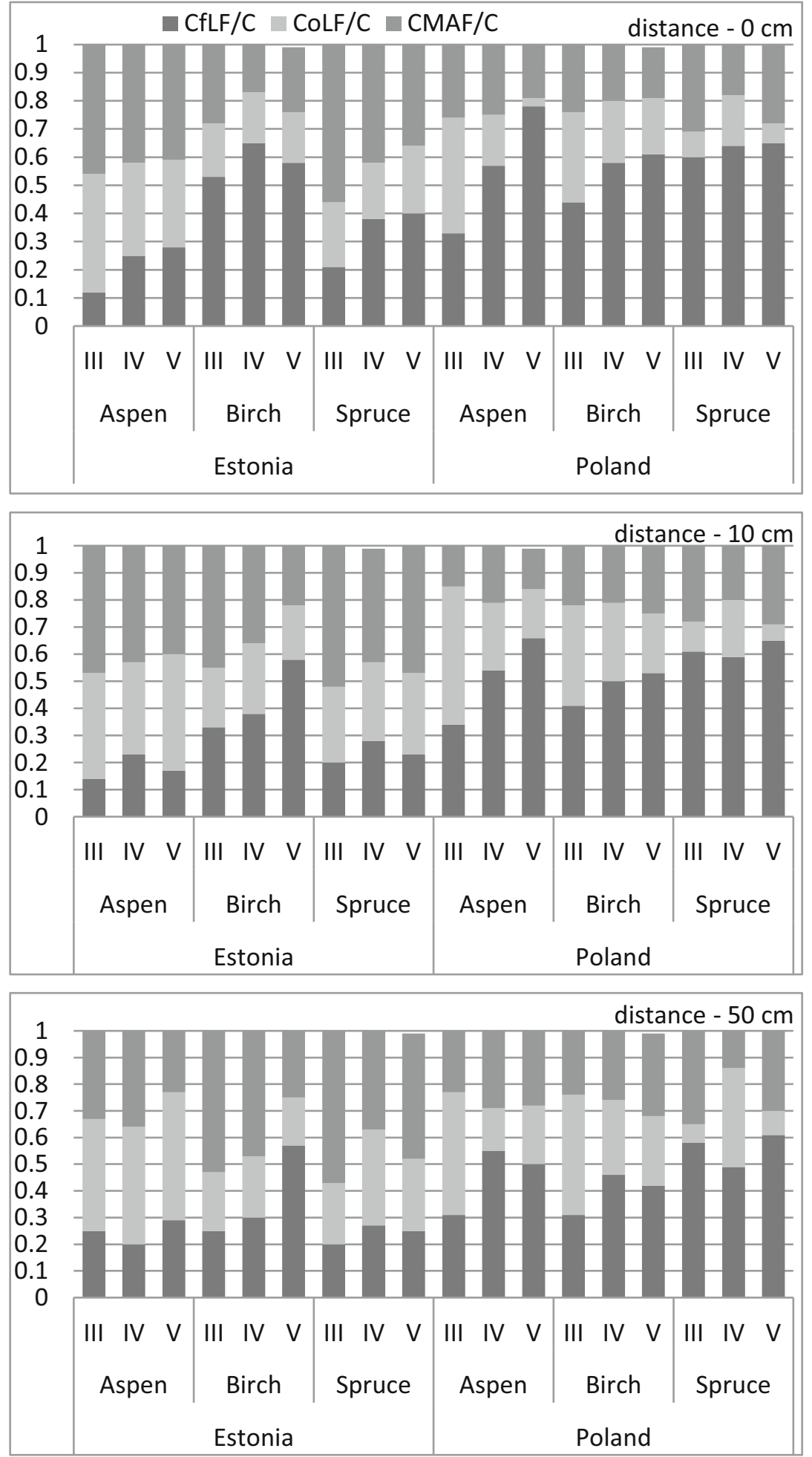

deadwood decomposition. This could explain the slower release of deadwood decomposition products in the Estonian sites and higher accumulation of free light fractions under logs and in their direct vicinity in the Polish forests. According to Woodall and Liknes (2008), increases in temperature and/or moisture are required for increases in forest production and subsequent forest detritus accumulations. Cool moist environments provide conditions capable of generating anaerobic conditions in downed deadwood, slowing decomposition, increasing the longevity of downed deadwood, and increasing the probability of burial (Moroni et al. 2015). Climate constitutes a major controlling factor for SOC 
Fig. 4 The projection of variables on a plane of the first and second PCA factor (C, carbon content; $\mathrm{C}_{\mathrm{fLF}}$, carbon of free light fraction; $\mathrm{C}_{\mathrm{oLF}}$, carbon of occluded light fraction; $\mathrm{C}_{\mathrm{MAF}}$, carbon of mineral associated fraction; $\mathrm{N}_{\mathrm{fLF}}$, nitrogen of free light fraction; $\mathrm{N}_{\mathrm{oLF}}$, nitrogen of occluded light fraction, $\mathrm{N}_{\mathrm{MAF}}$, nitrogen of mineral associated fraction; III-V, decay classes; $0,10,50$, distance from log; blue circles, soils in Poland; blue polygons, soils in Estonia)
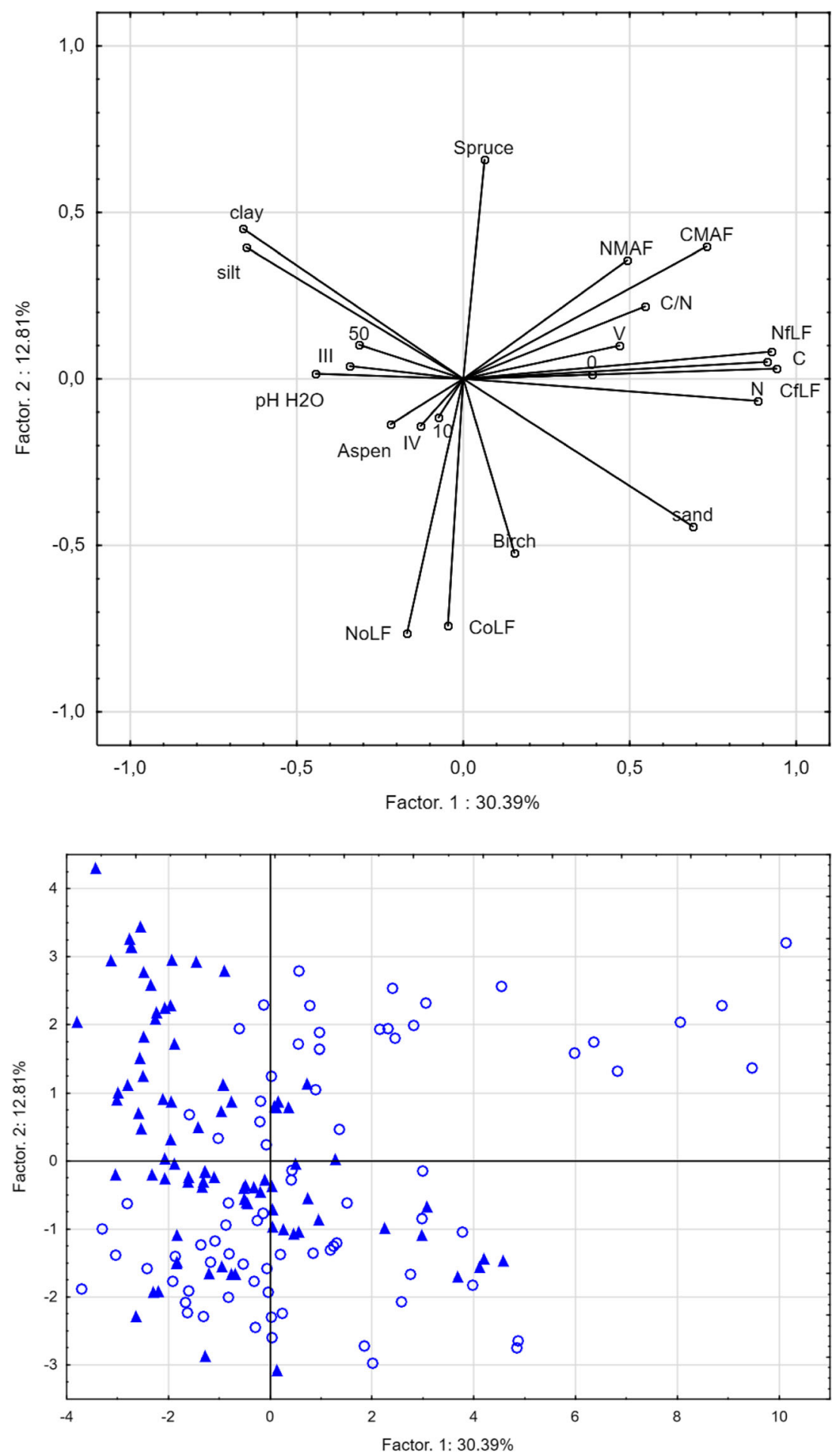

storage at regional to global scales; mean annual air temperature has proven to be a suitable indicator that could serve as indicator for SOC storage (Wiesmeier et al. 2019).

The effect of tree species that are subject to transformations during decomposition processes may have significant influences on the decomposition rates and decomposition processes. The main cause for this is the differences in the chemical composition of wood from different species (Laiho and Prescott 2004; Prescott and Laiho 2002). In general, the wood of coniferous species is less abundant in such macronutrients as $\mathrm{N}, \mathrm{P}, \mathrm{K}, \mathrm{Ca}$, and $\mathrm{Mg}$ than deciduous wood, and the higher content of resinous substances and the different chemical composition of the lignins may hinder the microbial 
Table 3 Summary of LMM analysis of the effect of experimental locality, species, decomposition rate (DC), and distance from deadwood on the carbon content and carbon of different SOM fractions in soil, significant effects $(p<0.05)$ are shown in italics

\begin{tabular}{|c|c|c|c|c|c|c|c|c|}
\hline & \multicolumn{2}{|l|}{$\mathrm{C}$} & \multicolumn{2}{|l|}{$\mathrm{C}_{\mathrm{fLF}}$} & \multicolumn{2}{|l|}{$\mathrm{C}_{\mathrm{oLF}}$} & \multicolumn{2}{|c|}{$\mathrm{C}_{\mathrm{MAF}}$} \\
\hline & $F$ & $p$ value & $F$ & $p$ value & $F$ & $p$ value & $F$ & $p$ value \\
\hline Experimental locality & 127.1 & 0.000 & 90.1 & 0.000 & 3.2 & 0.081 & 7.0 & 0.012 \\
\hline Species & 2.9 & 0.065 & 1.8 & 0.186 & 8.0 & 0.001 & 12.8 & 0.000 \\
\hline $\mathrm{DC}$ & 57.3 & 0.000 & 36.2 & 0.000 & 0.1 & 0.927 & 27.1 & 0.000 \\
\hline Distance & 208.4 & 0.000 & 156.4 & 0.000 & 8.6 & 0.000 & 46.1 & 0.000 \\
\hline DC:distance & 39.5 & 0.000 & 29.3 & 0.000 & 0.6 & 0.652 & 13.4 & 0.000 \\
\hline Experimental locality:species & 15.9 & 0.000 & 15.4 & 0.000 & 5.0 & 0.012 & 9.3 & 0.001 \\
\hline Experimental locality:DC & 18.9 & 0.000 & 10.9 & 0.000 & 1.0 & 0.378 & 24.4 & 0.000 \\
\hline Experimental locality:distance & 113.5 & 0.000 & 72.2 & 0.000 & 10.7 & 0.000 & 36.6 & 0.000 \\
\hline Experimental locality:DC:distance & 14.2 & 0.000 & 21.6 & 0.000 & 2.8 & 0.030 & 0.4 & 0.832 \\
\hline Experimental locality:species:DC & 6.8 & 0.000 & 5.4 & 0.002 & 0.8 & 0.525 & 4.1 & 0.007 \\
\hline Experimental locality:species:distance & 4.6 & 0.002 & 6.5 & 0.000 & 3.7 & 0.009 & 2.5 & 0.049 \\
\hline Species:DC & 1.8 & 0.141 & 1.0 & 0.435 & 2.0 & 0.108 & 10.2 & 0.000 \\
\hline Species:distance & 1.1 & 0.348 & 0.4 & 0.832 & 6.0 & 0.000 & 6.8 & 0.000 \\
\hline Species:DC:distance & 3.8 & 0.001 & 5.9 & 0.000 & 3.5 & 0.002 & 1.3 & 0.255 \\
\hline Experimental locality:species:DC:distance & 3.2 & 0.004 & 4.7 & 0.000 & 1.6 & 0.145 & 2.9 & 0.008 \\
\hline
\end{tabular}

processes of wood decomposition in coniferous species (Błońska et al. 2018; Kögel-Knabner 2002). In agreement with this, the positive effect of the share of deciduous trees volume on soil organic carbon stock has been observed in mixed forests at comparable sites in Estonia (Lutter et al. 2019). Under temperate climatic conditions, SOC stocks under coniferous species may be relatively high, as effect of acidic litter accumulation (Jandl et al. 2007). Our study has demonstrated the influence of the warmer sites in Poland on intensified decomposition and formation of primarily free light fraction SOM. It appears that, among the studied species, spruce wood in the harsher climate of Estonia had the slowest decomposition rate, which was indicated by the relatively low accumulation of soil humus. In these terms, aspen wood appears to possess better properties and a higher susceptibility to decomposition, which was significantly dependent on thermal conditions. The degree of SOM accumulation as well as the characters of humus under birch logs in our study was slightly different between spruce and aspen logs at the experimental sites. By comparing the amounts of carbon and nitrogen in the SOM free light fraction, only minor differences between the experimental locations were determined when comparing spruce to aspen. In the case of soil under birch logs, a significantly higher accumulation of nitrogen associated with occluded light fraction (oLF) was found for the warmer Polish climate. We believe that this stems from the release of bettermineralized deadwood decomposition products, which are bound with the soil mineral substance. The study of Lasota et al. (2017) demonstrated that birch wood releases large amounts of ammonium ions and nitrate anions at earlier decay classes. The intense leaching of these compounds to soil located under the log may be linked to the higher nitrogen concentrations in the fractions of SOM creating bonds with soil minerals.

The effect of deadwood on the content of soil organic matter is intensified for subsequent decay classes. At III DC, the increase of the SOM content in the warmer Polish climate was observed solely under the analyzed logs. In more advanced DC (IV and V), the influence of decaying wood on the SOM content was exhibited also nearer to $\operatorname{logs}$ (at up to $10 \mathrm{~cm}$ ). This is in line with the earlier study of Błońska et al. (2017). Wambsganss et al. (2017), who studied the accumulation of various SOM fractions under beech $\operatorname{logs}$ on two types of geological substrates, studied the increase of the content of SOM free light fraction and occluded light fraction on siliceous substrate. In our study, in the case of logs at advanced decay class (V DC) in Poland, we were able to record an increase of SOM mineral associated fraction under aspen and spruce logs (apart from the increase of free light fraction). Similar mineral content of associated fractions were determined in the case of birch logs at both locations studied. At the same time, in Poland, a higher content of $\mathrm{C}$ and $\mathrm{N}$ from the SOM occluded light fraction was determined for III DC directly under birch logs, which can be associated with the intense release of decomposition products from wood of this species at higher decomposition stages, which has been confirmed in earlier studies of the authors (Lasota et al. 2017). Soil organic matter fractions clearly exhibit the influence of 
decomposing wood regardless of location. As decay progresses, the share of individual SOM fractions changes. The light fraction of soil organic matter is more sensitive to deadwood effects than the heavy fraction. Free light fraction, since it is easily degradable and requires only a short circulation time, is used to indicate changes or disturbances in the amount of litter input (Crow et al. 2007; Krueger et al. 2016). SOM fractions analysis can be used to assess the stability and circulation of SOC between deadwood and soil in different experimental localities.

\section{Conclusions}

Our study has confirmed that deadwood of different tree species with different decomposition rates affects soil organic carbon sequestration in Estonia and Poland forests. A higher sequestration of carbon in surface soil horizons as an effect of the deadwood decomposition process has been determined in the Polish forests. The processes of soil organic matter transformations and deadwood decomposition in the Estonia forests had slower rates. The positive influence of the species studied on the SOM stabilization was also notable, but the effect differed among the species. More-decomposed deadwood impacts soil organic matter stabilization more strongly than less-decayed deadwood. This relationship was clearer in Poland. Higher temperature and longer growth period primarily influenced the increase of the concentration of free light fraction of SOM directly under and near logs of the species studied. The slower release of deadwood decomposition products was perceptible for the forests in Estonia. In the case of logs at advanced decomposition rates in Poland, the increase of the SOM mineral associated fraction under aspen and spruce logs was evident.

Funding information The project was financed by the National Science Centre, Poland: decision no. DEC-2016/21/D/NZ9/01333 and institutional research funding IUT (grants IUT21-4 and IUT 34-9) and the project P170053MIMK of the Estonian Ministry of Education and Research. The contribution of I. Ostonen was supported by Center of Excellence: EcolChange (the European Regional Development Fund). We acknowledge networking support by the COST Action FP1305 (Biolink).

Data availability The datasets generated during the current study are available in the Zenodo repository (Błońska et al. 2019) at https://doi.org/10.5281/zenodo.3386521

\section{Compliance with ethical standards}

Conflict of interest The authors declare that they have no conflict of interest.

Statement on ethical approval The authors confirm obtaining the permission to conduct the study in Czarna Rózga Reserve. The permission was issued by Regional Directorate for Environmental Protection in Łódź (Poland) (WPN-I.6205.78.2016.DB).

\section{Appendix}

Table 4 The basic chemical properties of investigated soils (depth $0-10 \mathrm{~cm})$

\begin{tabular}{lll}
\hline Soil properties & \multicolumn{2}{l}{ Experimental localities } \\
\cline { 2 - 3 } & Estonia & Poland \\
\hline $\mathrm{pH}_{\mathrm{H} 2 \mathrm{O}}$ & $4.88 \pm 0.61$ & $4.59 \pm 0.64$ \\
$\mathrm{pH}_{\mathrm{KCl}}$ & $3.95 \pm 0.56$ & $3.68 \pm 0.66$ \\
$\mathrm{C}$ & $47.1 \pm 18.8$ & $82.3 \pm 47.0$ \\
$\mathrm{~N}$ & $2.8 \pm 0.8$ & $4.6 \pm 2.2$ \\
$\mathrm{C} / \mathrm{N}$ & $16.95 \pm 2.84$ & $17.49 \pm 2.93$ \\
Sand & $57.16 \pm 11.64$ & $62.57 \pm 7.41$ \\
Silt & $38.55 \pm 10.57$ & $33.86 \pm 6.521$ \\
Clay & $4.06 \pm 1.07$ & $3.69 \pm 0.96$ \\
\hline
\end{tabular}

(Mean \pm Std. deviation); $\mathrm{C}$, carbon content $\left(\mathrm{g} \mathrm{kg}^{-1}\right) ; \mathrm{N}$, nitrogen content $\left(\mathrm{g} \mathrm{kg}^{-1}\right)$; sand, silt, and clay content $(\%)$

Table 5 Decay class characteristics by Maser et al. (1979)

Degree Criteria for evaluation

I Texture intact, circular, natural color of wood, bark intact, branches $<3 \mathrm{~cm}, \log$ leaning on branches

II Texture intact, circular, natural color of wood, bark slightly damaged, no branches $<3 \mathrm{~cm}, \log$ begins to sink

III Texture larger hard fragments, circular, faded color of wood, fragmented bark, no branches $<3 \mathrm{~cm}$, almost entire log on the ground

IV Texture small pieces, oval shape, faded color of wood, no bark, no branches $<3 \mathrm{~cm}$, entire log on the ground

V Texture soft and loose, oval shape, faded color of wood, no bark, no branches $<3 \mathrm{~cm}$, entire on the ground

Open Access This article is distributed under the terms of the Creative Commons Attribution 4.0 International License (http:// creativecommons.org/licenses/by/4.0/), which permits unrestricted use, distribution, and reproduction in any medium, provided you give appropriate credit to the original author(s) and the source, provide a link to the Creative Commons license, and indicate if changes were made.

\section{References}

Allison SD, LeBauer DS, Ofrecio MR, Reyes R, Ta AM, Tran TM (2009) Low levels of nitrogen addition stimulate decomposition by boreal forest fungi. Soil Biol Biochem 41:293-302

Allison SD, Lu Y, Weihe C, Goulden ML, Martiny AC, Treseder KK, Martiny JB (2013) Microbial abundance and composition influence litter decomposition response to environmental change. Ecology 94:714-725

Bani A, Pioli S, Ventura M, Panzacchi P, Borruso L, Tognetti R, Tonon G, Brusetti L (2018) The role of microbial community 
in the decomposition of leaf litter and deadwood. Appl Soil Ecol. https://doi.org/10.1016/j.apsoil.2018.02.017

Bardelli T, Gómez-Brandón M, Ascher-Jenull J, Fornasier F, Arfaioli P, Francioli D, Egli M, Sartori G, Insam H, Pietramellara G (2017) Effects of slope exposure on soil physico-chemical and microbiological properties along an altitudinal climosequence in the Italian Alps. Sci Total Environ 575:1041-1055

Błońska E, Lasota J (2017) Soil organic matter accumulation and carbon fractions along a moisture gradient of forest soils. Forests 448:1-13

Błońska E, Kacprzyk M, Spólnik A (2017) Effect of deadwood of different tree species in various stages of decomposition on biochemical soil properties and carbon storage. Ecol Res 32(2):193-203

Błońska E, Lasota J, Piaszczyk W (2018) Dissolved organic carbon and total nitrogen release from deadwood of different tree species in various stages of decomposition. J Soil Sci Plant Nutr. https://doi.org/10.1080/00380768.2018.1545517

Błońska E, Lasota J, Tullus A, Lutter R, Ostonen I (2019) Impact of deadwood decomposition on soil organic carbon sequestration in Estonian and Polish forests. Zenodo. V2. [Dataset]. https://doi.org/10.5281/zenodo.3386521

Christensen BT (1992) Physical fractionation of soil and organic matter in primary particle size and density separates. Adv Soil Sci 20:1-90

Crow SE, Swanston CW, Lajtha K, Brooks JR, Keirstead H (2007) Density fractionation of forest soils: methodological questions and interpretation of incubation results and turnover time in an ecosystem context. Biogeochemistry 85:69-90

Egli M, Hafner S, Derungs C, Ascher-Jenull J, Camin F, Sartori G, Raab G, Bontempo L, Paolini M, Ziller L, Bardelli T, Petrillo M, Abiven S (2016) Decomposition and stabilisation of Norway spruce needlederived material in Alpine soils using 13C-labelling approach in the field. Biogeochemistry 131:321-338

Fravolini G, Egli M, Derungs C, Cherubini P, Ascher-Jenull J, GómezBrandón M, Bardelli T, Tognetti R, Lombardi F, Marchetti M (2016) Soil attributes and microclimate are important drivers of initial deadwood decay in sub-alpine Norway spruce forests. Sci Total Environ 569-570:1064-1076

Fravolini G, Tognetti R, Lombardi F, Egli M, Ascher-Jenull J, Arfaioli P, Bardelli T, Cherubini P, Marchetti M (2018) Quantifying decay progression of deadwood in Mediterranean mountains forests. For Ecol Manag 408:228-237

Gómez-Brandón M, Ascher-Jenull J, Bardelli T, Fornasier F, Sartori G, Pietramellara G, Arfaioli P, Egli M, Beylich A, Insam H (2017a) Ground cover and slope exposure effects on micro- and mesobiota in forest soils. Ecol Indic 80:174-185

Gómez-Brandón M, Ascher-Jenull J, Bardelli T, Fornasier F, Fravolini G, Arfaioli P, Ceccherini MT, Pietramellara G, Lamorski K, Slawiński C, Bertoldi D, Egli M, Cherubini P, Insam H (2017b) Physicochemical and microbiological evidence of exposure effects on Picea abies - coarse woody debris at different stages of decay. For Ecol Manag 391:376-389

Grüneberg E, Schöning I, Hessenmöller D, Schulze ED, Weisser WW (2013) Organic layer and clay content control soil organic carbon stocks in density fractions of differently managed German beech forests. For Ecol Manag 303:1-10

Harmon ME, Sexton J (1996) Guidelines for measurements of woody detritus in forest ecosystems, vol 20. US LTER Network Office, Seattle

Harmon ME, Franklin JF, Swanson FJ, Sollins P, Gregory SV, Lattin JD, Anderson NH, Cline SP (1986) Ecology of coarse woody debris in temperate ecosystems. Adv Ecol Res 15:133-302

Jandl R, Lindner M, Vesterdal L, Bauwens B, Baritz R, Magedorn F, Johnson DW, Minkkinen K, Byrne KA (2007) How strongly can forest management influence soil carbon se-questration? Geoderma $137: 253-268$
Kahl T, Mund M, Bauhus J, Detlef SE (2012) Dissolved organic carbon from European beech logs: patterns of input to and retention by surface soil. Ecoscience 19:1-10

Kirschbaum MUF (1995) The temperature-dependence of soil organicmatter decomposition, and the effect of global warming on soil organic-C storage. Soil Biol Biochem 27:753-760

Knorr W, Prentice IC, House JIE, Holland EA (2005) Long-term sensitivity of soil carbon turnover to warming. Nature 433:298-301. https://doi.org/10.1038/nature03226

Kögel-Knabner I (2002) The macromolecular organic composition of plant and microbial residues as inputs to soil organic matter. Soil Biol Biochem 34:139-162

Krasnova A, Kukumägi M, Mander U, Torga R, Krasnov D, Noe SM, Ostonen I, Püttsepp U, Lillian H, Uri V, Lõhmus K, Sõber I, Soosaar $\mathrm{K}$ (2019) Carbon exchange in a hemiboreal mixed forest in relation to tree speciescomposition. Agric For Meteorol 275:11-23

Krueger I, Schulz C, Broken W (2016) Stock and dynamics of soil organic carbon and coarse woody debris in three managed and unmanaged temperate forests. Eur J For Res 136:123-137

Laiho R, Prescott CE (2004) Decay and nutrient dynamics of coarse woody debris in northern coniferous forests: a synthesis. Can J For Res 34:763-777

Lasota J, Błońska E, Piaszczyk W, Wiecheć M (2017) How the deadwood of different tree species in various stages of decomposition affected nutrient dynamics? Journal of Soil and Sediments 18:2759-2769

Lutter R, Kõlli R, Tullus A, Tullus H (2019) Ecosystem carbon stocks of Estonian pre-mature and mature managed forests: effects of site conditions and overstorey tree species. Eur J For Res 138:125-142

Magnússon RÍ, Tietema A, Cornelissen JHC, Hefting MM, Kalbitz K (2016) Sequestration of carbon from coarse woody debris in forest soils. For Ecol Manag 377:1-15

Maser C, Anderson RG, Cromak K, Williams JT, Martin RE (1979) Dead and down woody material. In: Wildlife habitats in managed forests: the blue mountains of Oregon and Washington. Thomas JW (eds) USDA Forest Service Agricultural Handbook 553:78-95

Moroni MT, Morris DM, Shaw C, Stokland JN, Harmon ME, Fenton NJ, Merganičová K, Merganič J, Okabe K, Hagemann U (2015) Buried wood: a common yet poorly documented form of deadwood. Ecosystems 18:605-628

Ostonen I, Truu M, Helmisaari HS, Lukac M, Borken W, Vanguelova E, Godbold DL, Lõhmus K, Zang U, Tedersoo L, Preem JK, Rosenvald K, Aosaar J, Armolaitis K, Frey J, Kabral N, Kukumägi M, Leppälammi-Kujansuu J, Lindroos AJ, Merilä P, Napa U, Nöjd P, Parts K, Uri V, Varik M, Truu J (2017) Adaptive root foraging strategies along a boreal-temperate forest gradient. New Phytol 215:977-991

Prescott CE, Laiho R (2002) The Nutritional significance of coarse woody debris in three rocky mountain coniferous forests. USDA Forest Service Gen Tech Rep PSW-GTR-181

R Core Team (2018) R: a language and environment for statistical computing. R Foundation for Statistical Computing, Vienna https://www.R-project.org

Saidy AR, Smernik RJ, Baldock J, Kaiser K, Sanderman J, Macdonald LM (2012) Effects of clay mineralogy and hydrous iron oxides on labile organic carbon stabilisation. Geoderma 173-174:104-110

Scharlemann JPW, Tanner EVJ, Hiederer R, Kapos V (2014) Global soil carbon: understanding and managing the largest terrestrial carbon pool. Carbon Manag 5:81-91

Shorohova E, Kapitsa E (2014) Influence of the substrate and ecosystem attributes on the decomposition rates of coarse woody debris in European boreal forests. For Ecol Manag 315:173-184

Shorohova E, Kuuluvainen T, Kangur A, Jõgiste K (2009) Natural stand structures, disturbance regimes andsuccessional dynamics in the Eurasian boreal forests: areview with special reference to Russian studies. Annals of Forest Science 66:201. 
Sohi SP, Mahieu N, Arah JRM, Madari B, Gaunt JL (2001) A procedure for isolating soil organic matter fractions suitable for modeling. Soil Sci Soc Amer J 65:1121-1128

StatSoft, Inc. (2012 STATISTICA (version 12.0). Computer software

Stergiadi M, Van der Perk M, de Nijs TCM, Bierkens MFP (2016) Effects of climate change and land management on soil organic carbon dynamics and carbon leaching in northwestern Europe. Biogeosciences 13:1519-1536

Tefs C, Gleixner G (2012) Importance of root derived carbon for soil organic matter storage in a temperate old-growth beech forest evidence from $\mathrm{C}, \mathrm{N}$ and ${ }^{14} \mathrm{C}$ content. For Ecol Manag 263:131-137

Thomas SC, MacLellan J (2004) Boreal and temperate forests, in forests and forest plants. In: Encyclopedia of Life Support Systems (EOLSS); UNESCO. Eolss Publishers, Oxford

Wambsganss J, Stuts KP, Lang F (2017) European beech deadwood can increase oil organic carbon sequestration in forest topsoils. For Ecol Manag 405:200-209

Wan Y, Lin E, Xiong W, Li Y, Guo L (2011) modeling the impact of climate change on soil organic carbon stock in upland soils in the 21 st century in China. Agriculture. Ecosyst Environ 141:23-31

Wiesmeier M, Poeplau C, Sierra CA, Maier H, Frühauf C, Hübner R, Kühnel A, Spörlein P, Geuß U, Hangen E, Schilling B, Von Lützow M, Kögel-Knabner J (2016) Projected loss of soil organic carbon in temperate agricultural soils in the 21 st century: effects of climate change and carbon input trends. Sci Rep 6:32525

Wiesmeier M, Urbanski L, Hobley E, Lang B, von Lützow M, MariSpiotta E, van Wesemael B, Robot E, Lie $\beta$ M, Garcia-Franco N,
Wollschläger U, Vogel HJ, Kögel-Knabner I (2019) Soil organic carbon storage as a key function of soils - a review of driversand indicators at various scales. Geoderma 333:149-162

Woodall CW, Liknes GC (2008) Climatic regions as an indicator of forest coarse and fine woody debris carbon stocks in the United States. Carbon Balance Manag 3:5

WRB (World Reference Base For Soil Resource) (2014) FAO, ISRIC and ISSS

von Lützow M, Kögel-Knabner I (2009) Temperature sensitivity of soil organic matter decomposition-what do we know? Biol Fertil Soils 46:1-15

Von Lützov M, Kögel-Knobner J, Ekschmitt K, Matzner E, Guggenberger G, Marschner B, Flessa H (2006) Stabilization of organic matter in temperate soils: mechanisms and their relevance under different soil conditions - a review. Eur J Soil Sci $57: 426-445$

Yin X (1999) The decay of forest woody debris: numerical modeling and implications based on some 300 data cases from North America. Oecologia 121:81-98

Zalamea M, González G, Ping CL, Michaelson G (2007) Soil organic matter dynamics under decaying wood in a subtropical wet forest: effect of tree species and decay stage. Plant Soil 296:173-185

Publisher's note Springer Nature remains neutral with regard to jurisdictional claims in published maps and institutional affiliations. 